\title{
Guidelines to the Practice of Anesthesia
}

\author{
Revised Edition 2018 \\ Canadian Journal of Anesthesia \\ Volume 65, Number 1
}

How does this statement differ from the 2017 Guidelines?

A numbered indexing system has been added to the Table of Contents and to the document to enhance the reader's ability to reference specific sections of the Guidelines.

In the text, several important content changes have been made and they are highlighted in grey. They relate to:

- the importance of systematically monitoring the quality of anesthetic care delivery,

- the use of cognitive aids for the management of critical perioperative emergencies,

- general principles and specific changes to recommendations for preoperative testing,

- the critical importance of maintaining patient normothermia perioperatively,

- enhancing structure, process and documentation of patient care handovers,

- the cautious use of non-depolarizing neuromuscular blocking agents including vigilant monitoring, and

- small but important changes related to recommendations for patient care and monitoring in the postanesthesia care unit and during patient transport.

\section{GUIDE D'EXERCICE DE L'ANESTHÉSIE}

\section{Édition révisée 2018}

\section{Journal canadien d'anesthésie \\ Volume 65, numéro 1}

Comment cet énoncé diffère-t-il des Lignes directrices de 2017 ?

Un système d'indexation numéroté a été ajouté à la Table des matières et au document afin d'aider le lecteur à se référer à des sections spécifiques du Guide.

Dans le texte, plusieurs modifications importantes ont été apportées au contenu; elles sont mises en évidence sur fond gris. Elles ont trait à :

- l'importance d'une surveillance méthodique de la qualité de la prestation de soins anesthésiques,

- le recours à des listes de contrôle et des aides cognitives pour la prise en charge des urgences périopératoires critiques,

- des principes généraux et des modifications spécifiques aux recommandations en matière d'examens préopératoires,

- l'importance cruciale du maintien de la normothermie du patient en période périopératoire,

- l'amélioration de la structure, du processus et de la documentation lors du transfert de soins des patients

- l'utilisation prudente des bloqueurs neuromusculaires non dépolarisants, y compris un monitorage vigilant, et

- des modifications, petites mais importantes, des recommandations concernant les soins aux patients et leur monitorage en salle de réveil et pendant le transport des patients. 


\section{Contents}

Preamble

1. Basic principles

2. Organization of anesthetic services

2.1 Responsibilities of the chief of anesthesia

2.2 Privileges in anesthesia

2.3 Fitness to practice

2.4 Residents

2.5 Ancillary personnel

3. Anesthetic equipment and anesthetizing location

3.1 Responsibilities of the healthcare facility

3.2 Waste gases

4. The preanesthetic period

4.1 Preoperative testing

4.2 Fasting guidelines

5. The anesthetic period

5.1 Preparation for anesthesia

5.2 Delegation of patient care

5.3 Patient monitoring

5.4 Required monitoring equipment

5.5 Perioperative temperature management

5.6 Records

6. The postanesthetic period

6.1 Recovery facility

6.2 Discharge of patients after day surgery

7. Guidelines for obstetric regional analgesia

7.1 Initiation of obstetric regional analgesia

7.2 Maintenance of regional analgesia during labour

7.3 Oral intake during labour

8. Guidelines for acute pain management using neuraxial analgesia

8.1 Administrative and educational policies

8.2 Policies for drug administration

8.3 Patient monitoring and management of adverse events

8.4 Epidurals and anticoagulation

9. Guidelines for the practice of anesthesia outside a hospital facility

9.1 Patient selection

9.2 Preoperative considerations

9.3 Conduct of anesthesia

Appendix 1: Canadian Standards Association-standards for equipment Appendix 2: American Society of Anesthesiologists' classification of physical status Appendix 3: Pre-anesthetic checklist

Appendix 4: Guidelines, standards, and other official statements available on the internet

Appendix 5: Position paper on anesthesia assistants: an official position paper of the Canadian Anesthesiologists' Society

Appendix 6: Position paper on procedural sedation: an official position paper of the Canadian Anesthesiologists' Society 
Table des matières

Préambule

1. Principes de base

\section{Organisation des services d'anesthésie}

2.1 Responsabilités du chef du département d'anesthésie

2.2 Privilèges d'exercice en anesthésie

2.3 Aptitude à la pratique

2.4 Résidents

2.5. Personnel de soutien

3 Matériel d'anesthésie et lieux convenant à l'anesthésie

3.1 Responsabilités de l'établissement de santé

3.2. Gaz résiduels

4 La période préanesthésique

4.1 Examens préopératoires

4.2. Lignes directrices concernant le jeûne

5 La période anesthésique

5.1 Préparation à l'anesthésie

5.2 Délégation des soins aux patients

5.3 Monitorage du patient

5.4 Matériel de monitorage requis

5.5 Prise en charge périopératoire de la température

5.6 Dossiers

6. La période postanesthésique

6.1 La salle de réveil

6.2 Congé des patients après chirurgie d'un jour

7. Lignes directrices pour l'analgésie régionale en obstétrique

7.1 Amorce de l'analgésie régionale en obstétrique

7.2 Maintien de l'analgésie régionale pendant le travail

7.3 Absorption orale pendant le travail

8. Lignes directrices pour la prise en charge de la douleur aiguë à l'aide de l'analgésie neuraxiale

8.1 Politiques administratives et éducatives

8.2 Politiques en matière d'administration de médicaments

8.3 Monitorage des patients et prise en charge des évènements indésirables

8.4 Péridurales et anticoagulation

9. Lignes directrices pour l'exercice de l'anesthésie hors du milieu hospitalier

9.1 Sélection des patients

9.2 Considérations préopératoires

9.3 Conduite de l'anesthésie

Annexe 1: Association canadienne de normalisation - Normes concernant le matériel

Annexe 2: Classification de l'état de santé des patients, selon l'American Society of Anesthesiologists

Annexe 3: Liste de vérification préanesthésique

Annexe 4: Lignes directrices, normes et autres énoncés officiels disponibles sur l'internet

Annexe 5: Exposé de principe sur les assistants en anesthésie : exposé de principe officiel de la Société canadienne des anesthésiologistes

Annexe 6: Exposé de principe sur la sédation consciente : exposé de principe officiel de la Société canadienne des anesthésiologistes 


\title{
Guidelines to the Practice of Anesthesia - Revised Edition 2018
}

\author{
Gregory Dobson, MD $\cdot$ Matthew Chong, MD $\cdot$ Lorraine Chow, MD • \\ Alana Flexman, MD · Matthew Kurrek, MD · Claude Laflamme, MD · \\ Annie Lagacé, MD · Shean Stacey, MD · Barton Thiessen, MD
}

Received: 24 August 2017/Accepted: 14 October 2017/Published online: 14 December 2017

(C) Canadian Anesthesiologists' Society 2017

Overview The Guidelines to the Practice of Anesthesia Revised Edition 2018 (the Guidelines) were prepared by the Canadian Anesthesiologists' Society (CAS), which reserves the right to determine their publication and distribution. The Guidelines are subject to revision and updated versions are published annually. The Guidelines to the Practice of Anesthesia Revised Edition 2018 supersedes all previously published versions of this document. Although the CAS encourages Canadian anesthesiologists to adhere to its practice guidelines to ensure high-quality patient care, the CAS cannot guarantee any specific patient outcome. Anesthesiologists should exercise their own professional judgement in determining the proper course of action for any patient's circumstances. The CAS assumes no responsibility or liability for any error or omission arising from the use of any information contained in its Guidelines to the Practice of Anesthesia.

Text Approved by CAS Board for 2018 Edition.

Texte approuvé par le Conseil de la SCA pour l'édition 2018.

Electronic supplementary materialThe online version of this article (http://doi.org/10.1007/s12630-017-0995-9) contains supplementary material, which is available to authorized users.

G. Dobson, MD $(\bowtie) \cdot M$. Chong, MD - L. Chow, MD ·

A. Flexman, MD · M. Kurrek, MD - C. Laflamme, MD ·

A. Lagacé, MD · S. Stacey, MD · B. Thiessen, MD

Canadian Anesthesiologists' Society, 1 Eglinton Avenue East,

Suite 208, Toronto, ON M4P 3A1, Canada

e-mail: standards@cas.ca; G.Dobson@Dal.Ca

\section{Preamble}

Anesthesiology is a dynamic specialty of medicine that fosters continuous improvements in anesthetic care for patients undergoing surgical and obstetric procedures in Canada. This document is reviewed annually and revised periodically.

The following recommendations are aimed at providing basic guidelines to anesthetic practice. They are intended as a framework for reasonable and acceptable patient care and should be interpreted as such to allow for some degree of flexibility in different circumstances. Each section of the Guidelines is subject to revision as warranted by the evolution of technology and practice.

\section{Basic principles}

In this document, the term anesthesiologist is used to designate all licensed medical practitioners with privileges to administer anesthetics. An anesthetic is the deliberate performance of any procedure to render a patient temporarily insensitive to pain or to the external environment so that a diagnostic or therapeutic procedure can be performed.

These Guidelines are intended to apply to all anesthesiologists in Canada. The independent practice of anesthesia is a specialized field of medicine, and as such, it should be practised by physicians with appropriate training in anesthesia. The only route to specialist recognition in anesthesia in Canada is through the certification process of the Royal College of Physicians and Surgeons of Canada. The Canadian Anesthesiologists' Society (CAS) acknowledges the fact that remote communities often lack the population base to support a specialist anesthesiology practice. In these 
communities, appropriately trained family physicians may be required to provide anesthesia services. In communities with the clinical volume to support full-time anesthesiologists, fellowship- certified anesthesiologists should provide these services. All anesthesiologists should continue their education in the practice of anesthesia, pain management, perioperative care, and resuscitation.

\section{Organization of anesthetic services}

The department of anesthesia should be properly organized, directed, and integrated with other departments in the organization or facility, and it should include all facility staff members who provide anesthetic services to patients for surgical, obstetric, diagnostic, and therapeutic purposes.

The department should be staffed appropriately, bearing in mind the scope and nature of the services it provides, and it should strive to ensure that these services are available as required by the healthcare facility.

The chief of the department should be a physician who has obtained certification or appropriate training in anesthesia. This individual should be appointed in the same manner as other chiefs of clinical departments and should be a member of the senior medical administrative bodies for the facility.

\subsection{Responsibilities of the chief of anesthesia}

1. To be aware of the current CAS Guidelines to the Practice of Anesthesia, the requirements of the Canadian Council on Health Services Accreditation, and the requirements of the provincial licensing authority as they relate to anesthesia;

2. To ensure that written policies with respect to the practice of anesthesia are established and enforced;

3. To evaluate the qualifications and abilities of the physicians providing anesthetic care as well as other health professionals providing ancillary care-this includes, but is not restricted to, recommending clinical privileges for physicians with anesthetic responsibilities and annually reviewing these privileges;

4. To employ a systematic approach for monitoring the quality of anesthetic care provided by members of the department of anesthesia throughout the healthcare facility;

Monitoring quality of care may include, but need not be restricted to, the use of chart audits, clinical indicator and outcome monitoring, adverse event reporting systems, morbidity and mortality conferences, and critical incident case reviews. The extent of quality improvement activities will vary depending on the departmental and health facility resources available to the chief. For effective quality improvement, it is strongly encouraged that all department members should actively participate in any such activities.

5. To ensure that records are kept for all anesthetic procedures - these records should allow for evaluation of all anesthetic care in the facility;

6. To carry out such other duties as the governing body of the facility may delegate to ensure safe anesthetic care;

7. To promote institutional compliance with applicable Canadian Standards Association (CSA) Standards (Appendix 1); and

8. To coordinate liaison between the departments of anesthesiology, biomedical engineering, and information management services.

\subsection{Privileges in anesthesia}

All physicians applying for privileges in anesthesia should demonstrate satisfactory completion of specialist postgraduate training in anesthesia. The standard is training in university programs approved by the Royal College of Physicians and Surgeons of Canada. International medical graduates approved for licensure by provincial regulatory bodies should demonstrate training equivalent to the Canadian standard. Family physicians practicing anesthesia should demonstrate satisfactory completion of a specific postgraduate program with at least one year of training. Special areas of anesthetic care may have specific concerns. The department of anesthesia in each institution may determine privileges in pediatric anesthesia according to the pediatric population it serves, the child's age, the presence of comorbidities, the physician's specific training and experience in pediatric anesthesia, and the complexity of the procedure involved.

Physicians with anesthetic privileges should possess the knowledge and technical and non-technical skills necessary for the practice of anesthesia.

Knowledge and technical skills include the ability:

- To provide preanesthetic evaluation of the patient and determine the appropriate anesthetic management;

- To render the patient insensible to pain for the performance of diagnostic and therapeutic procedures, surgical operations, and obstetric procedures;

- To monitor and support the vital organ systems during the perioperative period;

- To provide immediate postanesthetic management of the patient;

- To provide resuscitation and intensive care when indicated; and 
- To provide relief from acute and chronic pain.

Non-technical skills include:

- Task management: planning and preparing, prioritizing, providing and maintaining standards, and identifying and utilizing resources;

- Teamwork: coordinating activities with team members, exchanging information, using authority and assertiveness, assessing capabilities, supporting others, and supporting the World Health Organization Surgical Safety Checklist;

- Situational awareness: anticipating, gathering information, recognizing, and understanding, and;

- Decision-making: identifying options, balancing risks and selecting options, and re-evaluating.

\subsection{Fitness to practice}

The provision of anesthesia care requires anesthesiologists to have a high level of expertise, sound judgment, and the ability to recognize and respond to changing clinical situations despite sometimes adverse personal physical circumstances. Anesthesia departments must recognize that fit anesthesia practitioners provide optimal patient care. Anesthesia departments are therefore obligated to develop policies that ensure, as far as possible, that practitioners are healthy and fit to undertake their duties of practice.

A variety of factors impair health and fitness for duty, including adverse physical conditions, mental impairment, and fatigue. All these factors impair fitness and the ability to recognize and respond appropriately to often rapidly changing clinical circumstances. Many studies have shown that fatigue impairs judgement and psychomotor performance in a manner similar to drugs or alcohol. Shifting circadian rhythms, aging, and lack of sleep reinforce such problems; a fatigue-induced lack of recognition of these problems can compound the potential for errors in such circumstances. Physical impairment, illness, and severe stress can have similar detrimental effects on performance.

Anesthesia departments and individual anesthesiologists have a responsibility to organize their working duties such that illness and fatigue do not regularly affect clinical duties. Individual rosters must allow adequate rest between working shifts, and daily rosters should allow appropriate breaks for physiological needs, nutrition, and mental fitness. Operating room scheduling should avoid requiring anesthesiologists to undertake non-emergency procedures during unfavourable hours.

No specific prescription for working shifts and daily rosters can be appropriate for every working situation. Large departments have flexibility to incorporate short shifts and individual leave, while small departments may not have such freedom. Nevertheless, this important area of professional practice must receive ongoing consideration and attention.

\subsection{Residents}

Residents in anesthesia are registered medical practitioners who participate in the provision of anesthesia services both inside and outside the operating room as part of their training. The Royal College of Physicians and Surgeons of Canada and provincial and local regulatory authorities require that a responsible attending staff anesthesiologist must supervise all resident activities. The degree of this supervision must consider the condition of each patient, the nature of the anesthetic service, and the experience and capabilities of the resident (increasing professional responsibility). At the discretion of the supervising staff anesthesiologist, residents may provide a range of anesthetic care with minimal supervision. In all cases, the supervising attending anesthesiologist must remain readily available to give advice or assist the resident with urgent or routine patient care. Whether supervision is direct or indirect, close communication between the resident and the responsible supervising staff anesthesiologist is essential for safe patient care. Each anesthesia department teaching anesthesia residents should have policies regarding the activities and supervision of residents.

\subsection{Ancillary personnel}

The healthcare facility must ensure that ancillary personnel are available as assistants to the anesthesiologist. Such assistants must be available at all times and places where anesthetic services are provided. Ancillary personnel should have the competencies to meet the specific needs of subspecialty areas of anesthesia, reflecting on the need for specific skills in areas such as specialty pediatric anesthesia.

It is recommended that facilities have a formally designated anesthesia assistant with specific training in anesthesia assistance. The department of anesthesia and the appropriate administrative bodies must approve the scope of practice for anesthesia assistants working in a specific institution. Furthermore anesthesia assistants like other employed health professionals, must be covered by the facility's liability insurance. Duties and tasks delegated to anesthesia assistants must be consistent with existing governmental regulations, the policies and guidelines established by professional regulatory agencies, and the policies of the local facility.

An institution without formal anesthesia assistants must provide other paramedical personnel to assist the anesthesiologist. The tasks that these assistants may perform must 
be clearly defined. An anesthesiologist must only delegate or assign those tasks for which such personnel have approval or accreditation.

\section{Anesthetic equipment and anesthetizing location}

An anesthetic must be administered in an appropriate facility. All necessary equipment, including emergency equipment, life support systems, medications, and supplies must be readily available. It is strongly recommended that a cognitive aid manual be made available at all anesthetizing locations in support of the management of critical perioperative emergencies. The contents of the manual should be regularly reviewed and updated.

The healthcare facility, in consultation with the department of anesthesia, is responsible for the design and maintenance of preoperative, postoperative, and anesthetizing locations, as well as the purchase, maintenance, and disposal of anesthetic and ancillary equipment and supplies. The Canadian Standards Association (CSA) and other standards development organizations have published standards and guidance documents for the design, construction, and renovation of healthcare facilities and for the risk management, basic safety, and essential performance of medical equipment (Appendix 1).

\subsection{Responsibilities of the healthcare facility}

The healthcare facility must ensure that:

1. The operating rooms, anesthetizing locations, and perioperative care locations comply with at least the minimum design and construction requirements of the national, provincial, and local building, plumbing, electrical, HVAC (heating, ventilation, and air conditioning), fire, and security codes at the time of construction or renovation.

2. Medical gas and vacuum systems, waste anesthetic gas scavenging systems, terminal units, head walls, low pressure connecting assemblies, and pressure regulators meet the requirements of the CSA and are certified by a CSA-approved testing agency.

3. Oxygen concentrators that comply with CSA requirements are an acceptable substitute for bulk oxygen supply systems. When such concentrators are installed, users must be aware that:

a. The facility medical oxygen supply may deliver a fraction of inspired oxygen $\left(\mathrm{FiO}_{2}\right)$ that varies from 0.93 to 0.99 ; b. Oxygen analyzers must be calibrated against $100 \% \mathrm{O}_{2}\left(\mathrm{FiO}_{2} 0.99\right)$ and room air or equivalent $\left(\mathrm{FiO}_{2}\right.$ 0.21);

c. The use of low-flow (less than one litre total fresh gas flow) anesthetic techniques may result in the accumulation of inert gas (argon) and the dilution of nitrous oxide and oxygen in the circuit.

4. There is compliance with all safety regulations with respect to the storage, preparation, identification, labelling, disposal, and use of medical gases, medications, and related materials.

5. If general anesthesia is provided, electronic anesthetic systems comply with CAN/CSA- C22.2 No. 60601-2-13. An alternate means of ventilation (e.g., manual bag and mask resuscitator) must be immediately available with each anesthesia system. The workstations must be equipped with at least an oxygen analyzer, an airway pressure monitor, a waste anesthetic gas scavenging system, and a high vacuum tracheal suction system with a backup means of suction. If vaporizers are used, they must use an agent-specific filling system to ensure filling with the correct agent. If a ventilator is provided, it must have a low-pressure or disconnect alarm.

6. The equipment, supplies, and appropriate assistance necessary for the safe performance of invasive procedures are provided. Diagnostic equipment, such as, but not limited to nerve stimulators, ultrasound, image intensifiers, and $\mathrm{x}$-ray, should be available to the anesthesiologist as required. For the placement of central venous and arterial catheters, dedicated ultrasound capability must be provided by the facility. The use of real-time ultrasound guidance for elective internal jugular central venous catheter placement is strongly recommended when the anesthesia provider has training and experience with the technique.

7. An "Arrest Cart" containing emergency resuscitation equipment including a manual resuscitator, a defibrillator complying with current Canadian Heart and Stroke Association Guidelines, and appropriate medications and intravenous equipment is immediately available. A 'Pediatric Arrest Cart' containing pediatric resuscitation equipment must be immediately available in any location where sedation, anesthesia, or resuscitation of children is performed. A length-based pediatric emergency tape kit ( ${ }^{\text {B Broselow }}{ }^{\mathrm{TM}}$ ) may facilitate the conduct of the resuscitation process.

8. If Malignant Hyperthermia triggering agents are used, a "Malignant Hyperthermia Kit" complying with the recommendations of the Malignant 
Hyperthermia Association of the United States shall be immediately available (Appendix 4).

9. A "Difficult Airway Kit" for difficult or failed airway management is immediately available. Facilities that care for children must have specialized pediatric airway equipment immediately available.

10. Facilities that care for children should have specialized pediatric equipment. Wherever obstetric anesthesia is performed, a separate area for newborn assessment and resuscitation must be provided. This area must include designated oxygen, suction apparatus, electrical outlets, a source of radiant heat, and equipment for neonatal airway management and resuscitation.

11. Personal protection devices, including N95 masks, face masks, and means of disposal of hazardous and infectious wastes and sharps are provided. Surgical, diagnostic, therapeutic, and esthetic settings must have plume scavenging systems complying with CSA Z305.13-09.

12. Oxygen supplies for transport of perioperative patients must be provided. The use of transport oxygen cylinders capable of providing an audible low-pressure alarm is strongly recommended.

13. Qualified personnel conduct regular inspections and maintenance of all anesthetic and ancillary equipment. The facility administration and the department of anesthesia must retain records indicating conformity to regulations and inspection and maintenance.

Anesthesia providers must ensure that potentially infectious materials or agents are not transferred from one patient to another. Special attention in this regard should be given to syringes, infusion pump administration sets, and multi-dose drug vials.

Training on the safe use of all anesthesia equipment should be provided to all anesthesia department members prior to use. Attendance at these sessions should be documented. These training sessions should be repeated as necessary for new or established department members.

\subsection{Waste gases}

Recommendations for reducing occupational exposure to waste anesthetic gases:

1. Dilution ventilation at the rate of 20 exchanges per hour should be provided in all anesthetizing locations where volatile anesthetic gases or $\mathrm{N}_{2} \mathrm{O}$ are used.

2. Recirculation of exhaust air shall not be permitted during the hours when operations may be in progress, and it is not recommended at any other time.
3. Wherever an anesthetic delivery system is used, a scavenger shall be provided to capture anesthetic gases that might be released from the anesthetic circuit or ventilator.

4. A maintenance program shall be established in each healthcare facility to detect and repair leakage from the anesthetic delivery system and to maintain the effectiveness of the waste anesthetic scavenging unit.

5. The healthcare facility shall be responsible for conducting regular monitoring of exposure to waste anesthetic gases. The monitoring protocol should include individuals and the air flow patterns of the rooms being assessed. When $\mathrm{N}_{2} \mathrm{O}$ is used in the operating room, $\mathrm{N}_{2} \mathrm{O}$ monitoring is a suitable representation for the assessment of adequacy of scavenging.

\section{The preanesthetic period}

The department of anesthesia should establish policies regarding preanesthetic assessment.

The primary goal of preanesthetic assessment is to obtain the information required to plan anesthetic management. Accordingly, a physician who is knowledgeable about anesthetic management for the proposed diagnostic or therapeutic procedure should document all aspects of the patient's medical and surgical history, findings on physical examination, and laboratory investigations that are relevant to anesthetic management. The patient's history should include past and current medical problems, current and recent drug therapy, unusual reactions or responses to drugs, and any problems or complications associated with previous anesthetics. A family history of adverse reactions associated with anesthesia should also be obtained. Information about the anesthetic that the patient considers relevant should also be documented. An American Society of Anesthesiologists physical status classification (Appendix 2) should be recorded for each patient.

In appropriate cases, the availability of an "Advance Care Plan" (representation agreement, advanced directive, "living will", "do not resuscitate" directive, etc.) should be ascertained, and its applicability to the proposed intervention should be determined and documented on the anesthetic assessment record.

The surgeon may request consultation with an anesthesiologist. Medical consultations should be obtained when indicated.

Preoperative anesthetic assessment or consultation may take place in an outpatient clinic before admission for the operative procedure. Indications for pre-admission assessment include the presence of significant medical problems (comorbidities), the nature of the proposed diagnostic or 
therapeutic procedure, and patient request. A parent/guardian must be present if the patient is a child or not competent to provide informed consent. All patients should be informed that arrangements will be made to meet with an anesthesiologist if they wish to discuss anesthetic management before admission to the facility. The preoperative assessment clinic should also allow nursing and other healthcare personnel to assess the patient. The attending anesthesiologist is responsible for performing a final preanesthetic assessment in the immediate preoperative period.

\subsection{Preoperative testing}

Laboratory testing should not be performed on a routine basis but should be obtained only when results will change perioperative management. Laboratory investigations should be performed when indicated by the patient's medical status, drug therapy, and the nature of the proposed procedure. Routine laboratory blood testing, electrocardiograms, and chest radiographs are not recommended for asymptomatic patients having low-risk surgery. Examples of low-risk surgery include, but are not restricted to, cataract surgery, minor breast surgery, superficial procedures, and many minor ambulatory procedures. For more detailed definitions of low-risk surgery and for other recommendations related to preoperative testing, visit Choosing Wisely on the CAS website and the associated Internet links.

Reasonable indications for specific tests include:

\begin{tabular}{lc}
\hline Test & Indications \\
\hline Complete blood count & - Major surgery requiring group \\
& and screen or group and match \\
& Chronic cardiovascular, \\
& pulmonary, renal, or hepatic \\
& disease \\
& - Malignancy \\
& Known or suspected anemia, \\
& bleeding diathesis, or myelo- \\
& suppression \\
- Patient less than one year of & age \\
Sickle cell screen & Genetically predisposed patient \\
& (hemoglobin electrophoresis \\
International normalized ratio & if screen is positive) \\
(INR), activated partial & Anticoagulant therapy \\
thromboplastin time & Bleeding diathesis \\
& $\bullet$ Liver disease
\end{tabular}

continued

\begin{tabular}{|c|c|}
\hline Test & Indications \\
\hline $\begin{array}{l}\text { Electrolytes and } \\
\text { creatinine levels }\end{array}$ & $\begin{array}{l}\text { - Hypertension } \\
\text { - Renal disease } \\
\text { - Diabetes } \\
\text { - Pituitary or adrenal disease } \\
\text { - Digoxin or diuretic therapy or other drug } \\
\text { therapies affecting electrolytes }\end{array}$ \\
\hline Fasting glucose level & $\begin{array}{l}\text { - Diabetes (should be repeated on day of } \\
\text { surgery) }\end{array}$ \\
\hline Pregnancy ( $\beta$-HCG) & - Woman who may be pregnant \\
\hline Electrocardiography & $\begin{array}{l}\text { May be considered for patients with known } \\
\text { or suspected coronary heart disease, } \\
\text { significant arrhythmia, peripheral vascular } \\
\text { disease, or other significant structural heart } \\
\text { disease } \\
\text { - May be considered in the absence of } \\
\text { symptoms or known cardiovascular disease } \\
\text { in patients having intermediate or high-risk } \\
\text { surgery in the presence of clinical risk } \\
\text { factors (e.g., Revised Cardiac Risk Index } \\
\text { (RCRI) or American College of Surgeons } \\
\text { (ACS) Surgical Risk Calculator) }\end{array}$ \\
\hline Chest radiograph & $\begin{array}{l}\text { - Not recommended for asymptomatic } \\
\text { patients in the routine preoperative } \\
\text { assessment unless part of a surgical or } \\
\text { oncological workup unrelated to } \\
\text { perioperative risk assessment } \\
\text { - May be considered for patients with acute } \\
\text { or chronic cardiopulmonary disease based } \\
\text { on history and physical exam if it will } \\
\text { change management }\end{array}$ \\
\hline
\end{tabular}

\subsection{Fasting guidelines}

Fasting policies should vary to account for age and preexisting medical conditions and should apply to all forms of anesthesia, including monitored anesthesia care. Emergent or urgent procedures should be undertaken after considering the risk of delaying surgery $v s$ the risk of aspiration of gastric contents. The type and amount of food ingested should be considered in determining the duration of fasting.

Before elective procedures, the minimum duration of fasting should be

- Eight hours after a meal that includes meat or fried or fatty foods;

- Six hours after a light meal (such as toast and a clear fluid) or after ingestion of infant formula or non-human milk;

- Four hours after ingestion of breast milk (no additions to pumped breast milk are allowed);

- Two hours after clear fluids. 
Unless contraindicated, adults and children should be encouraged to drink clear fluids (including water, pulp-free juice, and tea or coffee without milk) up to two hours before elective surgery.

Premedication, when indicated, should be ordered by the anesthesiologist. Orders should be specific as to dose, time, and route of administration.

Provincial legislation or facility bylaws may dictate additional regulations governing the conduct of anesthesia.

\section{The anesthetic period}

\subsection{Preparation for anesthesia}

Before beginning anesthesia, the anesthesiologist must ensure that

1. An explanation of the planned anesthetic procedure, including recognized risks and alternative techniques, has been provided and documented;

2. An adequate review of the patient's condition has been performed;

3. All equipment that is expected to be required is available and in working order, including the equipment required for supporting core temperature management (patient core temperature $36-37^{\circ} \mathrm{C}$ );

4. A reserve source of oxygen under pressure is available;

5. All drugs and agents that are expected to be required are correctly identified-user-applied drug labels should conform to the CSA Standard CAN/CSAZ264.3-98 (R2005) (Appendix 1);

6. Until a specific connection system is devised for neuraxial use, both sides of all Luer connections are labelled; and

7. The manufacturers' recommendations concerning the use, handling, and disposal of anesthetic equipment and supplies have been considered.

\subsection{Delegation of patient care}

The anesthesiologist's primary responsibility is to the patient receiving care. The anesthesiologist or an anesthesia assistant supervised by the anesthesiologist shall remain with the patient at all times throughout the conduct of all general, major regional, and monitored intravenous anesthetics until the patient is transferred to the care of personnel in an appropriate care unit.

If the attending anesthesiologist leaves the operating room temporarily, he/she must delegate care of the patient to another anesthesiologist, a resident in anesthesia, or an anesthesia assistant. When the attending anesthesiologist delegates care to a resident in anesthesia or an anesthesia assistant, the attending anesthesiologist remains responsible for the anesthetic management of the patient. Before delegating care of the patient to an anesthesia assistant, the anesthesiologist must ensure that the patient's condition is stable and that the anesthesia assistant is familiar with the operative procedure and the operating room environment and equipment. The attending anesthesiologist must remain immediately available when care is delegated to an anesthesia assistant.

An anesthesiologist may briefly delegate routine care of a stable patient to a competent person who is not an anesthesia assistant only under the most exceptional circumstances, e.g., to provide life-saving emergency care to another patient. That person's only responsibility would be to monitor the patient during the anesthesiologist's absence and to keep the anesthesiologist informed until he/she returns. In this situation, the anesthesiologist remains responsible for the care of the patient and must inform the operating room team.

An intraoperative handover of care between two anesthesiologists should be documented in the anesthesia record and follow a structured protocol.

It is unacceptable for one anesthesiologist to simultaneously administer general anesthesia, major regional anesthesia (spinal, epidural, or other), or deep procedural sedation (levels 4-6 Ramsay Sedation Scale [RSS], see Appendix 6) for concurrent diagnostic or therapeutic procedures on more than one patient. Nevertheless, it may be appropriate in specific circumstances for one anesthesiologist to supervise more than one patient where only RSS 1-3 sedation is administered, provided an appropriately trained, qualified, and accredited individual approved by the healthcare institution is in constant attendance with each patient receiving care. In an obstetric unit, however, it is acceptable to supervise more than one patient receiving regional analgesia for labour. Due care must be taken to ensure that a suitably trained person adequately observes each patient following an established protocol. When an anesthesiologist is providing anesthetic care for an obstetric delivery, a second appropriately trained person should be available to provide neonatal resuscitation.

It is unacceptable for a single physician to administer an anesthetic and simultaneously perform a diagnostic or therapeutic procedure, except for procedures done with only infiltration of local anesthetic.

\subsection{Patient monitoring}

The only indispensable monitor is the presence, at all times, of a physician or an anesthesia assistant who is under the immediate supervision of an anesthesiologist and has 
appropriate training and experience. Mechanical and electronic monitors are, at best, aids to vigilance. Such devices assist the anesthesiologist to ensure the integrity of the vital organs and, in particular, the adequacy of tissue perfusion and oxygenation.

The healthcare facility is responsible for the provision and maintenance of monitoring equipment that meets current published equipment standards.

The chief of anesthesia is responsible for advising the healthcare facility regarding the procurement of monitoring equipment and for establishing policies for monitoring to help ensure patient safety.

The anesthesiologist is responsible for monitoring the patient receiving care and for ensuring that appropriate monitoring equipment is available and working correctly. A preanesthetic checklist (Appendix 3 or equivalent) shall be completed prior to initiation of anesthesia.

Cautious dosing, vigilant monitoring, and the appropriate reversal of neuromuscular blocking drugs are all essential for patient safety. Neuromuscular monitoring should be utilized when non-depolarizing neuromuscular blocking agents are administered.

Monitoring guidelines for standard patient care apply to all patients receiving general anesthesia, regional anesthesia, or intravenous sedation.

\subsection{Required monitoring equipment}

Monitoring equipment is classified as follows:

- Required: These monitors must be in continuous use throughout the administration of all anesthetics.

- Exclusively available for each patient: These monitors must be available at each anesthetic work station so that they can be used with no delay.

- Immediately available: These monitors must be available to facilitate their use without undue delay.

The following monitoring equipment is required:

- Pulse oximeter;

- Apparatus to measure blood pressure, either directly or noninvasively;

- Electrocardiography;

- Capnography for general anesthesia and deep procedural sedation (RSS 4-6); and

- Agent-specific anesthetic gas monitor, when inhalational anesthetic agents are used.

The following monitoring equipment shall be exclusively available for each patient:

- Apparatus to measure temperature;

- Peripheral nerve stimulator, when neuromuscular blocking drugs are used;
- Stethoscope- precordial, esophageal, or paratracheal; and

- Appropriate lighting to visualize an exposed portion of the patient.

The following monitoring equipment shall be immediately available:

- Spirometer to measure tidal volume;

- Manometer to measure endotracheal tube cuff pressure.

The anesthesiologist must remain constantly vigilant, understanding that brief interruptions in continuous monitoring may be unavoidable and there are certain circumstances in which a monitor may fail.

Audible and visual alarms for oximetry and capnography should not be indefinitely disabled during the conduct of an anesthetic except during unusual circumstances. The variable pitch, pulse tone, and low- threshold alarm of the pulse oximeter and the capnograph apnea alarm must give an audible and visual warning.

\subsection{Perioperative temperature management}

Monitoring patient core temperature is strongly recommended during cases of general and neuraxial regional anesthesia lasting $30 \mathrm{~min}$ or longer. In the absence of surgical or patient indications for intraoperative hypothermia, active patient warming systems, control of the operating room ambient temperature, and other methods, should be used to target a central core temperature of $36-$ $37^{\circ} \mathrm{C}$.

\subsection{Records}

All monitored physiologic variables should be charted at intervals appropriate to the clinical circumstances. Heart rate and blood pressure should be recorded at least every five minutes. Oxygen saturation must be monitored continuously and should be recorded at frequent intervals for all patients. End-tidal carbon dioxide concentration must be monitored continuously and recorded at frequent intervals if the trachea is intubated. Reasons for deviation from these charting guidelines should be documented in the anesthetic record. Monitors, equipment, and techniques, as well as time, dose, and route of all drugs and fluids should be recorded. Intraoperative care should be recorded.

The anesthesia record should include the patient's level of consciousness, heart rate, blood pressure, oxygen saturation, and respiratory rate as first determined in the postanesthesia care unit (PACU). 


\section{The postanesthetic period}

\subsection{Recovery facility}

A postanesthesia care unit (PACU) must be available in any facility that provides anesthetic services. Administrative policies to coordinate medical and nursing care responsibilities shall be enforced in accordance with facility bylaws.

The department of anesthesia should have overall medical administrative responsibility for the PACU. There should be a PACU policy manual approved by appropriate medical, nursing, and administrative authorities.

The anesthesiologist should accompany the patient to the PACU, communicate necessary information to the PACU nurse(s) as part of a structured handover of care protocol, and write appropriate orders. If clinically indicated, supplemental oxygen and appropriate monitoring devices, such as, but not restricted to, portable pulse oximetry, should be applied during transport to the PACU. The anesthesiologist should delegate care to the PACU nurse only when assured that nursing staff may safely observe and care for the patient. The anesthesiologist or designated alternate is responsible for providing anesthetic-related care in the PACU. Discharge from the PACU is the responsibility of the anesthesiologist; this responsibility may be delegated in accordance with facility policy.

Supplemental oxygen and suction must be available for every patient in the PACU. Emergency equipment for airway management, resuscitation, and life support must be available in the PACU. Equipment for management of the difficult airway must be immediately available to the PACU. The monitoring used in the PACU should be appropriate to the patient's condition, and a full range of monitoring devices should be available. Monitor alarms should be enabled with alarm settings appropriate to the condition and age of the patient. The use of continuous pulse oximetry is required in the initial phase of recovery. Capnography is required for intubated or deeply sedated (RSS 4-6) patients. An apnea monitor is recommended for preterm infants with a gestational age of less than 50 weeks.

An accurate record of the immediate recovery period shall be maintained. This must include a record of vital signs together with other aspects of treatment and observation. The recovery record shall form a part of the permanent medical record. Any complications that bear any relation to the anesthetic should be recorded either on the recovery record or on the progress notes on the patient's chart.

In some circumstances, it may be considered acceptable to transfer a patient directly to other care units or to bypass the PACU if the appropriate level of care is available in another unit in the facility and the suitability of the patient for this transfer is documented on the anesthetic record.

\subsection{Discharge of patients after day surgery}

Discharge of patients after day surgery must be through the use of a formal care plan approved by the institution and documented in the patient care notes. Specific written instructions should include management of pain and postoperative complications, and both routine and emergency follow-up. The patient should be advised regarding the additive effects of alcohol and other sedative drugs, the danger of driving or operating other hazardous machinery during the postoperative period (most commonly $24 \mathrm{hr}$ postoperatively), and the necessity for attention by a competent adult during the postoperative period (most commonly $24 \mathrm{hr}$ postoperatively).

\section{Guidelines for obstetric regional analgesia}

Anesthesia services for parturients include obstetric analgesia for labour-for both uncomplicated and complicated deliveries-or for operative deliveries. All guidelines regarding provision of anesthesia for other diagnostic or therapeutic procedures also apply to the provision of obstetric anesthesia. The guidelines in this section pertain to epidural and spinal analgesia during labour. The term "regional analgesia" includes epidural, spinal, and combined spinal-epidural analgesia.

These guidelines are reviewed annually by the Obstetric Anesthesia Section of CAS and updated as indicated. Each facility may choose to develop additional guidelines or policies for specific situations in which obstetric regional analgesia is provided.

Under the direction of an anesthesiologist, some aspects of monitoring and management of obstetric regional analgesia may be delegated to other healthcare personnel. Each facility should ensure that such other personnel receive the same training, certification, continuing education, and recertification in obstetric regional analgesia.

\subsection{Initiation of obstetric regional analgesia}

1. Before introducing obstetric regional analgesia, the facility should have appropriate monitoring protocols in place. These protocols should outline the types of monitoring required and the frequency of monitoring. In addition, they should clearly state how to manage common problems and emergencies and indicate whom to contact if assistance is required. 
2. Obstetric regional analgesia should be provided only by physicians with training, facility privileges, and licence to provide these services. This includes trainees with appropriate supervision.

3. Regional analgesia should be initiated and maintained only in locations where appropriate resuscitation equipment and drugs are immediately available.

4. Informed consent should be obtained and documented in the medical record.

5. Intravenous access must be established before initiating regional analgesia, and it should be maintained throughout the administration of regional analgesia.

6. The anesthesiologist should be immediately available until analgesia is established and the patient's vital signs are stable.

\subsection{Maintenance of regional anesthesia during labour}

Continuous infusions of low-dose (diluted) epidural local anesthetics, with or without other adjuncts, are associated with a very low incidence of significant complications. Consequently, it is not necessary for an anesthesiologist to remain present or immediately available during maintenance of continuous epidural infusion analgesia provided that

- There are appropriate protocols for management of patients receiving patient-controlled epidural analgesia (PCEA), and

- The anesthesiologist can be contacted for the purpose of obtaining advice and direction.

A bolus dose of local anesthetic through the epidural catheter or through a catheter or needle presumed to be in the epidural space can cause immediate life-threatening complications. For this reason, an anesthesiologist must be available to intervene appropriately should any complications occur when a bolus dose of local anesthetic is injected through the epidural catheter (except PCEA). Individual departments of anesthesiology should establish their own policies regarding the appropriate availability of an anesthesiologist to manage any complications of regional analgesia. In developing these policies, each department should consider the possible risk of bolus injection of local anesthetics and the methods of dealing with emergency situations.

\subsection{Oral intake during labour}

Gastric emptying of solids is delayed during labour and opioid analgesics may further delay gastric emptying. Therefore, parturients should not eat solid foods once they are in established labour. In contrast to solid food, clear liquids are emptied relatively rapidly from the stomach and absorbed in the proximal small bowel, including during labour. Therefore, individual facilities should develop protocols regarding the intake of clear liquids by women in established labour.

\section{Guidelines for acute pain management using neuraxial analgesia}

When neuraxial analgesia is managed by anesthesiologists, the incidence of side effects is no higher than when alternative techniques of pain management are used. Accordingly, when its use is appropriate, neuraxial analgesia should be managed by anesthesiologists.

For the purposes of these guidelines, neuraxial analgesia is defined as intrathecal or epidural administration of opioids and/or local anesthetics for treatment of postoperative pain or other acute pain problems. These guidelines are to provide anesthesiologists with the principles of management to maximize the benefit-risk ratio of providing neuraxial analgesia.

\subsection{Administrative and educational policies}

The department of anesthesia should establish an acute pain service that is responsible for

1. Developing policies and procedures for neuraxial analgesia. Participation of other departments (e.g., nursing, pharmacy, surgery, and materials management) should be sought as needed.

2. Liaison with the surgical departments. Surgeons need to understand the criteria for patient selection, the effects of neuraxial analgesia on the normal postoperative course and on the presentation of postoperative complications, and the implications of other therapies, such as prophylactic anticoagulation, on neuraxial analgesia.

3. Education and certification of nurses. A standardized educational program-with initial training, certification, and ongoing maintenance of competence-should be established for nurses caring for patients receiving neuraxial analgesia.

Nursing personnel should understand

- The risk of respiratory depression, including delayed respiratory depression when hydrophilic opioids are used;

- Assessment and management of respiratory depression;

- Assessment of motor and sensory blockade;

- Assessment and management of hypotension in patients receiving neuraxial analgesia; and 
- Signs and symptoms of the rare but catastrophic complications of epidural hematoma or abscess.

\subsection{Policies for drug administration}

Each facility should use a limited number of standard solutions. A preprinted order sheet listing the standard solutions for the facility is strongly recommended. Before any solution that is not standard in the facility is dispensed, the anesthesiologist should verify the order with nursing and pharmacy personnel and discuss its indications and all concerns relating to its use with the nurses responsible for administering the drug and monitoring the patient.

The risk of errors due to incorrect route of drug injection must be minimized. For continuous infusions or PCEA, the use of unique tamper-proof pumps that are distinct from the pumps used for intravenous fluid or drug administration is strongly recommended. The tubing between neuraxial analgesia infusion pumps and catheters should not have ports that could permit unintentional injection of intravenous drugs.

Preparation of solutions should follow a standardized procedure. All analgesic drug solutions should be labelled with the composition of the solution (opioid, local anesthetic, or both) and its intended route of administration (epidural or intravenous).

\subsection{Patient monitoring and management of adverse events}

Patients receiving neuraxial analgesia should be in a room equipped with oxygen and suction. Resuscitation drugs and equipment must be immediately available. Before initiating neuraxial analgesia, intravenous access must be secured, and after discontinuing neuraxial analgesia, intravenous access must be maintained for the expected duration of drug effects.

Epidural catheter dressings should permit examination for catheter movement and daily inspection of the catheter entry site for any signs of infection.

Standardized policies for patient management should be established. The parameters to be assessed, frequency of assessments, documentation, and procedures for management of complications should be specified. Adequate nursing personnel must be available to assess and manage patients receiving neuraxial analgesia. Monitoring should continue after discontinuation of neuraxial analgesia until its effects have dissipated.

An anesthesiologist must be readily available to advise nursing personnel on such issues as dose titration and management of adverse effects. Each facility with an acute pain service should ensure that an anesthesiologist is available to attend directly to patients receiving neuraxial analgesia within an appropriate time depending on the clinical situation. Each facility should also specify procedures for emergent management of any life-threatening complications.

Other drugs, particularly benzodiazepines or parenteral opioids, may cause severe respiratory depression in patients receiving neuraxial analgesia. For this reason, other physicians should not order sedatives or analgesics for any patient receiving neuraxial analgesia. The acute pain service should direct analgesic and sedative therapy until the effects of neuraxial analgesia have dissipated.

\subsection{Epidurals and anticoagulation}

Patients with epidural catheters may receive prophylactic low-dose anticoagulant therapy if appropriate precautions are taken:

- To minimize the risk of epidural hematoma, catheter insertion and removal and the timing of anticoagulant administration must be coordinated so that no clinically significant anticoagulant effect is present at these times.

- Use of nonsteroidal anti-inflammatory drugs in patients receiving neuraxial analgesia is appropriate, but concurrent administration of these drugs or other antiplatelet medication and an anticoagulant may increase the risk of epidural hematoma.

- Where neuraxial analgesia is used for prolonged postoperative pain management, every effort should be made to avoid lower extremity motor blockade.

- Nursing staff should be aware of the signs and symptoms of epidural hematoma. Any change in neurologic status or new-onset back pain must be investigated immediately.

If full anticoagulation is indicated in a patient with an epidural catheter, the anesthesiologist should be consulted so that catheter removal and initiation of alternative analgesic management are accomplished before anticoagulation.

\section{Guidelines for the practice of anesthesia outside a hospital facility}

The basic principles, training requirements, techniques, equipment, and drugs used for the practice of anesthesia are noted in other sections of these guidelines. The following are guidelines for certain aspects particular to anesthetic practice outside a hospital facility. 


\subsection{Patient selection}

The physical status of patients should be classified in a manner similar to that in use by the American Society of Anesthesiologists (ASA) (Appendix 2). Usually, only patients in ASA classifications I and II should be considered for anesthesia outside a hospital facility. Patients in ASA classification III may be accepted under certain circumstances.

\subsection{Preoperative considerations}

The patient must have had a recent recorded history, physical examination, and appropriate laboratory investigations. These may be carried out by another physician or anesthesiologist. The duration of fasting before anesthesia should conform to the previously stated guidelines. The patient should be given an information sheet with instructions for both the pre- and postanesthetic periods.

\subsection{Conduct of anesthesia}

The anesthetic and recovery facilities shall conform to facility standards published by the CSA as defined in other sections. The standards of care and monitoring shall be the same in all anesthetizing locations.

Acknowledgements Contributions to earlier versions of the Guidelines from former members of the Committee on Standards to the Practice of Anesthesia are gratefully acknowledged.

Competing interests All authors of this article are members of the Standards Committee of the Canadian Anesthesiologists' Society (CAS). None of the authors have any financial or commercial interest relating to the companies or manufacturers of medical devices referenced either in this article or in the related appendices. Dr. Gregory Dobson is Chair of the Committee on Standards of the CAS.
Appendix 2: American Society of Anesthesiologists classification of physical status

Available as Electronic Supplementary Material.

\section{Appendix 3: Preanesthetic checklist}

Available as Electronic Supplementary Material.

Appendix 4: Guidelines, standards, and other official statements available on the internet

Appendix 4 (available at: http://www.cas.ca/English/ Guidelines) provides a non-exhaustive list of sites with official statements promulgated by other related medical organizations both in Canada and worldwide. This list is provided solely for the convenience of CAS members. The CAS is not responsible for the accuracy, currency, or reliability of the content. The CAS does not offer any guarantee in this regard. It is not responsible for the information found through these links and does not necessarily endorse the sites or their content. This list includes sites that are updated periodically.

Appendix 5: Position paper on anesthesia assistants: an official position paper of the Canadian

Anesthesiologists' Society

Available as Electronic Supplementary Material.

Appendix 6: Position paper on procedural sedation: an official position paper of the Canadian

Anesthesiologists' Society

Available as Electronic Supplementary Material.

\section{Appendix 1: Canadian Standards Association- standards for equipment}

Available as Electronic Supplementary Material. 


\section{Guide d'exercice de l'anesthésie - Édition révisée 2018}

Résumé Le Guide d'exercice de l'anesthésie, version révisée 2018 (le Guide), a été préparé par la Société canadienne des anesthésiologistes (SCA), qui se réserve le droit de décider des termes de sa publication et de sa diffusion. Le Guide est soumis à révision et des versions mises à jour sont publiées chaque année. Le Guide d'exercice de l'anesthésie, version révisée 2018, remplace toutes les versions précédemment publiées de ce document. Bien que la SCA incite les anesthésiologistes $d u$ Canada à se conformer à son guide d'exercice pour assurer une grande qualité des soins dispensés aux patients, elle ne peut garantir les résultats d'une intervention spécifique. Les anesthésiologistes doivent exercer leur jugement professionnel pour déterminer la méthode d'intervention la mieux adaptée à l'état de leur patient. La SCA n'accepte aucune responsabilité ou imputabilité de quelque nature que ce soit découlant d'erreurs ou d'omissions ou de l'utilisation des renseignements contenus dans son Guide d'exercice de l'anesthésie.

\section{Préambule}

L'anesthésiologie est une spécialité dynamique de la médecine qui encourage les progrès constants en matière de soins anesthésiques pour les patients subissant des interventions chirurgicales et obstétricales au Canada. Le présent guide est revu annuellement et révisé de façon périodique.

Les recommandations suivantes ont pour objectif de proposer des lignes directrices de base touchant l'exercice de l'anesthésie. Leur but est de constituer un cadre pour la prestation de soins aux patients qui soient raisonnables et acceptables, et c'est ainsi qu'elles devraient être interprétées, ce qui permet une certaine flexibilité selon les circonstances. Chaque partie du Guide peut faire l'objet de révision au besoin, selon l'évolution de la technologie et de la pratique.

\section{Principes de base}

Dans le présent document, le mot anesthésiologiste est utilisé pour désigner toute personne qui a un permis d'exercer la médecine avec privilège d'administrer l'anesthésie. L'anesthésie est la réalisation délibérée de toute intervention visant à rendre un patient temporairement insensible à la douleur ou à l'environnement externe dans le but d'exécuter une intervention diagnostique ou thérapeutique.

Le présent Guide s'adresse à tous les anesthésiologistes du Canada. L'exercice indépendant de l'anesthésie est une spécialité médicale et, à ce titre, elle doit être exercée par des médecins ayant une formation appropriée en anesthésie. Le processus de certification du Collège royal des médecins et chirurgiens du Canada constitue la seule voie de reconnaissance comme spécialiste en anesthésie au Canada. La Société canadienne des anesthésiologistes (SCA) reconnaît que la population dans les collectivités éloignées n'est souvent pas suffisamment nombreuse pour justifier une pratique d'anesthésiologie spécialisée. Dans ces collectivités, des médecins de famille ayant reçu une formation adéquate pourraient être appelés à dispenser les services d'anesthésie. Dans les communautés où le volume clinique est suffisamment important pour justifier l'emploi d'anesthésiologistes à temps plein, des anesthésiologistes ayant complété leur spécialisation devraient offrir ces services. Tous les anesthésiologistes devraient poursuivre une formation continue dans la pratique de l'anesthésie, de la prise en charge de la douleur, des soins périopératoires et de la réanimation.

\section{Organisation des services d'anesthésie}

Le département d'anesthésie devrait être organisé, dirigé et intégré de façon appropriée aux autres départements de l'organisme ou de l'établissement, et devrait regrouper tous les membres du personnel de l'établissement qui assurent des soins anesthésiques aux patients, aussi bien à des fins chirurgicales, obstétricales, diagnostiques ou thérapeutiques.

Compte tenu de l'ampleur et de la nature des services offerts, le département devrait comporter le personnel nécessaire et s'efforcer d'assurer que ces services soient disponibles comme l'établissement de soins de santé le requiert.

Le chef du département devrait être un médecin certifié en anesthésie ou encore possédant une formation adéquate en anesthésie. Cette personne devrait être nommée de la même manière que les autres chefs de départements cliniques et devrait faire partie des entités administratives médicales supérieures de l'établissement.

2.1 Responsabilités du chef du département d'anesthésie

1. Connaître les directives du présent Guide d'exercice de l'anesthésie de la SCA ainsi que les exigences du 
Conseil canadien d'agrément des services de santé et celles du Collège des médecins de la province en ce qui a trait à l'anesthésie.

2. Veiller à ce que, en matière d'exercice de l'anesthésie, des directives écrites soient établies et suivies.

3. Évaluer la compétence et les capacités des médecins qui dispensent les soins anesthésiques ainsi que celles des autres professionnels de la santé qui assurent les services de soutien - ce qui comprend, sans cependant s'y limiter, les recommandations touchant les privilèges cliniques accordés aux médecins qui exercent l'anesthésie et la révision annuelle de tels privilèges.

4. Avoir recours à une approche systématique pour surveiller la qualité des soins anesthésiques offerts par les membres du département d'anesthésie à la grandeur de l'établissement de soins de santé.

La surveillance de la qualité des soins peut comprendre, sans cependant s'y limiter, le recours à des vérifications de dossiers, la surveillance d'indicateurs et de suivis cliniques, les systèmes de surveillance des évènements indésirables, des conférences sur la morbidité et la mortalité, et la révision des cas d'incidents critiques. L'étendue des activités d'amélioration de la qualité variera selon les ressources départementales et institutionnelles mises à la disposition du chef de département. Pour une amélioration efficace de la qualité, tous les membres du département sont fortement encouragés à prendre une part active à de telles activités.

5. Veiller à conserver un dossier pour toute procédure d'anesthésie. Ces dossiers doivent permettre de procéder à l'évaluation de l'ensemble des soins anesthésiques dans l'établissement.

6. S'acquitter de toute autre tâche que la direction de l'établissement pourrait lui confier pour assurer des soins anesthésiques sécuritaires.

7. Promouvoir la conformité aux normes applicables de l'Association canadienne de normalisation (CSA) au sein de l'établissement (Annexe 1).

8. Coordonner la liaison entre le département d'anesthésiologie et les services de génie biomédical et de gestion de l'information.

\subsection{Privilèges d'exercice en anesthésie}

Tous les médecins qui demandent le privilège d'exercer l'anesthésie devraient avoir complété avec succès une formation postdoctorale spécialisée en anesthésie. La norme est une formation dans l'un des programmes universitaires approuvés par le Collège royal des médecins et chirurgiens du Canada. Les diplômés en médecine en provenance d'autres pays et dont la licence a été approuvée par les organismes de règlementation provinciaux devraient avoir complété une formation équivalente à la norme canadienne. Les médecins de famille pratiquant l'anesthésie doivent avoir complété avec succès un programme postdoctoral spécifique comprenant au moins un an de formation. Certains domaines spécifiques des soins anesthésiques peuvent avoir des préoccupations qui leur sont propres. Le département d'anesthésie de chaque institution peut déterminer les privilèges en anesthésie pédiatrique, selon la population pédiatrique que l'institution dessert, l'âge de l'enfant, la présence de comorbidités, la formation spécifique du médecin et son expérience en anesthésie pédiatrique, ainsi que la complexité de l'intervention en question.

Les médecins qui obtiennent le privilège d'exercer l'anesthésie devraient posséder les connaissances ainsi que les habiletés techniques et non techniques indispensables à la pratique de l'anesthésie.

Ces connaissances et ces compétences techniques comprennent la capacité de :

- Effectuer une évaluation préanesthésique du patient et décider de la prise en charge anesthésique appropriée;

- Rendre le patient insensible à la douleur pour la pratique des interventions diagnostiques et thérapeutiques, ainsi que des interventions chirurgicales et obstétricales;

- Monitorer et soutenir les fonctions vitales des organes en période périopératoire;

- Assurer la prise en charge postanesthésique immédiate du patient;

- Pratiquer des manœuvres de réanimation et procurer des soins intensifs lorsque indiqué; et

- Procurer le soulagement de la douleur aiguë et chronique.

Les compétences non techniques comprennent :

- La gestion des tâches : planification et préparation, priorisation, prestation et maintien des normes, et identification et utilisation des ressources;

- Le travail en équipe : coordination des activités avec les membres de l'équipe, échange des informations, usage de l'autorité et de l'affirmation de soi, évaluation des capacités, soutien aux autres, et respect de la Liste de contrôle de la sécurité chirurgicale de l'Organisation mondiale de la santé;

- La conscience situationnelle : anticipation, récolte des informations, identification et compréhension; et

- La prise de décision : identification des options, évaluation des risques et choix des options, réévaluation. 


\subsection{Aptitude à la pratique}

La prestation de soins anesthésiques requiert que l'anesthésiologiste possède un niveau élevé d'expertise, un bon jugement et la capacité de reconnaître des situations cliniques changeantes et d'y réagir et ce, malgré des circonstances physiques personnelles parfois défavorables. Les départements d'anesthésie doivent être conscients que des praticiens en anesthésie en santé fournissent des soins optimaux aux patients. Par conséquent, les départements d'anesthésie ont l'obligation de mettre au point des politiques qui garantissent, dans la mesure du possible, que les praticiens soient en bonne santé et aptes à remplir les obligations liées à leur pratique.

Plusieurs facteurs peuvent affecter négativement la santé et l'aptitude au travail, notamment les maladies physiques, les troubles mentaux et la fatigue. Tous ces facteurs altèrent la santé et l'aptitude à reconnaître des circonstances cliniques évoluant souvent très rapidement et à y réagir de façon adaptée. De nombreuses études ont démontré que la fatigue altérait le jugement et la performance psychomotrice de façon semblable aux drogues ou à l'alcool. Des rythmes circadiens irréguliers, le vieillissement et le manque de sommeil aggravent de tels problèmes; une non-reconnaissance de ces problèmes, causée par la fatigue, peut augmenter la probabilité de commettre des erreurs dans de telles circonstances. Un handicap physique, la maladie et un stress important peuvent avoir des effets néfastes semblables sur la performance.

La responsabilité incombe aux départements d'anesthésie et aux anesthésiologistes en tant qu'individus d'organiser leurs tâches professionnelles de telle sorte que la maladie et la fatigue n'affectent pas régulièrement leurs tâches cliniques. Les listes de garde de chacun doivent permettre un repos adapté entre les quarts de travail, et les listes quotidiennes doivent allouer des pauses adaptées afin de respecter les besoins physiologiques, la nutrition et l'aptitude mentale de chaque anesthésiologiste. La planification des salles d'opération devrait éviter d'exiger que les anesthésiologistes entreprennent des interventions non urgentes pendant des heures défavorables.

Aucune recommandation spécifique concernant les quarts de travail et la liste de garde quotidienne ne peut être adaptée à toutes les situations de travail. Les grands départements disposent de la flexibilité nécessaire à intégrer des quarts de travail courts et des congés personnels, alors que les départements plus petits pourraient ne pas jouir de cette liberté. Toutefois, ce domaine important de l'exercice professionnel doit faire l'objet d'une attention et d'une considération constantes.

\subsection{Résidents}

Les résidents en anesthésie sont des médecins autorisés qui participent à la prestation des soins anesthésiques tant en salle d'opération qu'à l'extérieur de celle-ci dans le cadre de leur formation. Le Collège royal des médecins et chirurgiens $\mathrm{du}$ Canada et les organismes de règlementation provinciaux et locaux exigent qu'un anesthésiologiste responsable supervise toutes les activités des résidents. Le degré de supervision doit prendre en considération l'état de chaque patient, la nature des soins anesthésiques, ainsi que l'expérience et les capacités du résident (responsabilité professionnelle croissante). À la discrétion de l'anesthésiologiste superviseur, les résidents peuvent fournir une gamme de soins anesthésiques sous un minimum de supervision. Dans tous les cas, l'anesthésiologiste superviseur doit demeurer promptement disponible afin de prodiguer des conseils ou d'assister le résident lors de soins urgents ou de routine. Que la supervision soit directe ou indirecte, une communication étroite entre le résident et l'anesthésiologiste superviseur est essentielle pour garantir des soins sécuritaires aux patients. Chaque département d'anesthésie qui enseigne aux résidents en anesthésie doit avoir des politiques en place concernant les activités et la supervision des résidents.

\subsection{Personnel de soutien}

L'établissement de soins de santé doit s'assurer de la disponibilité de personnel de soutien pour remplir un rôle d'assistance auprès de l'anesthésiologiste. Cette assistance doit être disponible en tout temps et en tout lieu où des services d'anesthésie sont offerts. Le personnel de soutien doit posséder les compétences nécessaires à répondre aux besoins spécifiques des domaines de surspécialité de l'anesthésie, ce qui se répercute sur le besoin de compétences spécifiques dans des domaines tels que l'anesthésie spécialisée en pédiatrie.

On recommande aux établissements de disposer d'un assistant en anesthésie formellement désigné qui aura reçu une formation spécifique en assistance en anesthésie. Le département d'anesthésie et les autorités administratives compétentes doivent approuver l'étendue des tâches des assistants en anesthésie travaillant dans un établissement en particulier. En outre, les assistants en anesthésie, tout comme les autres professionnels de la santé employés par l'établissement, doivent être protégés par l'assurance-responsabilité de l'établissement. Les responsabilités et les tâches déléguées aux assistants en anesthésie doivent être conformes aux règlements gouvernementaux en vigueur, aux politiques et lignes directrices édictées par les organismes de règlementation de la profession, et aux politiques de l'établissement local. 
Un établissement ne disposant pas d'assistants en anesthésie en bonne et due forme doit mettre à disposition de l'anesthésiologiste du personnel paramédical afin de l'assister. Les tâches incombant à ces assistants doivent être clairement définies. Un anesthésiologiste ne doit leur déléguer ou impartir que les tâches pour lesquelles ils ont été autorisés ou approuvés.

\section{Matériel d'anesthésie et lieux convenant à l'anesthésie}

L'anesthésie doit se pratiquer dans un établissement adapté. Tout le matériel nécessaire, y compris le matériel d'urgence, les systèmes de soutien des fonctions vitales, les médicaments et les autres fournitures, doit être à portée de main. Il est fortement recommandé qu'un manuel de listes de contrôle et d'aides cognitives soit disponible dans tous les lieux où l'anesthésie est pratiquée afin de soutenir la prise en charge des urgences périopératoires critiques. Le contenu de ce manuel devrait être révisé et mis à jour régulièrement.

L'établissement de soins de santé, en consultation avec le département d'anesthésie, est responsable de l'aménagement et de l'entretien des lieux servant aux soins préopératoires, postopératoires et anesthésiques, ainsi que de l'achat, de l'entretien et du traitement après utilisation du matériel et des fournitures servant à l'anesthésie et aux autres fonctions connexes. L'Association canadienne de normalisation (CSA) et d'autres organismes d'élaboration de normes ont publié des normes et des recommandations se rapportant à la conception, la construction et la rénovation des établissements de santé, ainsi que concernant la gestion du risque, la sécurité de base et les performances essentielles du matériel médical (Annexe 1).

\subsection{Responsabilités de l'établissement de santé}

Il incombe à l'établissement de soins de santé de veiller à l'application des mesures suivantes:

1. Les salles d'opération, d'anesthésie et de soins périopératoires doivent respecter au minimum les exigences minimales d'aménagement et de construction des codes nationaux, provinciaux et locaux concernant la charpente, la plomberie, l'électricité, le CVC (chauffage, ventilation et climatisation), la protection incendie et les codes de sécurité au moment de leur construction ou de leur rénovation.

2. Les systèmes d'évacuation des gaz médicaux et de vidange, les systèmes de récupération des gaz anesthésiques, les unités terminales, les murs de soutien, les raccordements à basse pression et les régulateurs de pression doivent être conformes aux exigences de la CSA et porter le sceau d'approbation d'une agence de vérification reconnue par la CSA.

3. Les concentrateurs d'oxygène conformes aux normes de la CSA sont un substitut acceptable à l'oxygène fourni par un système central. Lorsque de tels concentrateurs sont installés, il faut savoir :

a. Que l'approvisionnement d'oxygène médical de l'établissement peut dispenser une fraction d'oxygène inspirée $\left(\mathrm{FiO}_{2}\right)$ variant entre 0,93 et 0,99;

b. Que les analyseurs d'oxygène doivent être calibrés avec de 1 'O $\mathrm{O}_{2}$ à $100 \%$ (soit $\mathrm{FiO}_{2}$ 0,99) et à l'air ambiant ou l'équivalent (soit $\mathrm{FiO}_{2}$ $0,21)$;

c. Que l'utilisation de techniques anesthésiques à faible débit (moins d'un litre de gaz frais total) peut entraîner une accumulation de gaz inerte (argon) et la dilution du protoxyde d'azote dans le circuit.

4. L'entreposage, la préparation, l'identification, l'étiquetage, l'élimination et l'utilisation des gaz médicaux, des médicaments et du matériel afférent doivent être conformes à toutes les règles de sécurité.

5. En cas d'anesthésie générale, les systèmes d'anesthésie électroniques doivent répondre à la norme CAN/CSA-C22.2 No. 60601-2-13. Une autre méthode de ventilation (par ex. un ballon manuel et un masque de réanimation) doivent être à portée de main à côté de chaque appareil d'anesthésie. Les stations de travail doivent disposer d'au moins un analyseur d'oxygène, un moniteur de la pression des voies aériennes, un système d'évacuation des gaz anesthésiques résiduels et un appareil de succion trachéale puissant avec un dispositif supplémentaire de succion. En cas d'utilisation de vaporisateurs, ceux-ci doivent utiliser un dispositif de remplissage spécifique à chaque agent afin de garantir le remplissage par le bon agent. S'il y a un ventilateur, il doit être muni d'une alarme de basse pression ou de déconnexion.

6. Le matériel, les fournitures et l'aide nécessaires à l'exécution sécuritaire de procédures invasives sont disponibles. Des appareils de diagnostic, tels que, entre autres, les neurostimulateurs, les appareils d'échographie, les amplificateurs d'image et les appareils de radiographie, devraient être à la disposition de l'anesthésiologiste au besoin. Des dispositifs d'échographie dédiés doivent être mis à disposition par l'établissement pour l'installation de cathéters veineux centraux et artériels. Le recours à l'échoguidage en temps réel pour le positionnement 
non urgent d'un cathéter veineux central jugulaire interne est fortement recommandé lorsque le personnel qui administre l'anesthésie possède la formation et l'expérience avec cette technique.

7. Un « chariot de réanimation » comprenant le mate'

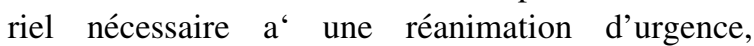
y compris un dispositif de réanimation manuelle, un défibrillateur respectant les Lignes directrices actuelles de la Fondation canadienne des maladies du cœur, les médicaments adapte's et les dispositifs intraveineux, doit être à portée de main. Un « chariot de réanimation pédiatrique » contenant du matériel de réanimation pédiatrique doit être à portée immédiate dans tout endroit où la sédation, l'anesthésie ou la réanimation d'enfants est réalisée. Une trousse d'urgence pédiatrique comprenant un ruban de Broselow ${ }^{\mathrm{TM}}$ pourrait faciliter le déroulement du processus de réanimation.

8. En cas d'utilisation d'agents déclencheurs d'hyperthermie maligne, une « Trousse d'hyperthermie maligne » respectant les lignes directrices de l'Association d'hyperthermie maligne des États-Unis sera à portée immédiate (Annexe 4).

9. Une « Trousse pour voies aériennes difficiles » sera à portée immédiate pour la prise en charge des voies aériennes difficiles ou lors d'un échec d'intubation.

10. Les établissements qui prennent soin d'enfants doivent disposer d'équipements pour voies aériennes pédiatriques spécialisés à portée immédiate. Dans tous les endroits où l'on pratique l'anesthésie obstétricale, un endroit spécifique réservé à l'évaluation et à la réanimation du nouveau-né doit être prévu. Cet endroit doit être pourvu de sources d'oxygène, d'appareils de succion, de prises de courant dédiés, ainsi que d'une source de chaleur radiante et de matériel nécessaire à la prise en charge des voies aériennes et à la réanimation néonatale.

11. Des dispositifs de protection personnelle, y compris des masques N95, des masques faciaux et des moyens d'élimination des déchets dangereux et infectieux ainsi que des objets aiguisés, sont à portée de main. Les environnements chirurgicaux, diagnostiques, thérapeutiques et esthétiques doivent disposer de systèmes d'aspiration de fumée respectant la norme CSA Z305.13-09.

12. Une alimentation en oxygène doit être fournie pour le transport des patients périopératoires. L'utilisation de cylindres de transport d'oxygène qui peuvent émettre une alarme audible lorsque la pression est faible est fortement recommandée.

13. Le personnel compétent inspecte et entretient régulièrement tout le matériel d'anesthésie et connexe. L'administration de l'établissement et le département d'anesthésie conserveront les documents attestant de la conformité aux règlements, des inspections et de l'entretien.

Le personnel qui administre l'anesthésie doit s'assurer qu'on ne transmet pas de substances ou d'agents potentiellement infectieux d'un patient à un autre. À cet égard, une attention particulière doit être portée aux seringues, aux tubulures des pompes à perfusion et aux fioles de médicaments multidoses.

Avant d'introduire tout nouvel appareil en anesthésie, tous les membres du département d'anesthésie doivent recevoir une formation concernant son utilisation sécuritaire. La participation à ces séances doit être documentée. Ces séances de formation doivent être répétées aussi souvent que nécessaire pour les nouveaux et anciens membres du département.

\subsection{Gaz résiduels}

Recommandations visant à diminuer l'exposition professionnelle aux gaz anesthésiques résiduels :

1. Une ventilation par dilution assurant 20 renouvellements par heure doit être disponible dans toutes les salles d'anesthésie dans lesquelles des gaz anesthésiques volatils ou du $\mathrm{N}_{2} \mathrm{O}$ sont utilisés.

2. La recirculation de l'air vicié ne sera pas permise durant les heures d'activité de la salle d'opération et n'est pas recommandée en toute autre période.

3. Partout où un système d'administration de gaz anesthésiques est utilisé, un système d'évacuation doit être mis en place afin de recueillir les gaz anesthésiques qui peuvent s'échapper du circuit d'anesthésie ou du ventilateur.

4. Un programme d'entretien doit être mis en place dans chaque établissement de soins de santé afin de détecter et de réparer toute fuite du système de distribution des gaz anesthésiques et de veiller au bon fonctionnement du système d'évacuation des gaz anesthésiques résiduels.

5. L'établissement de santé sera responsable d'effectuer une surveillance régulière de l'exposition aux gaz anesthésiques résiduels. Le protocole de surveillance devrait inclure les individus et la distribution de l'écoulement de l'air dans les salles évaluées. Lorsque le $\mathrm{N}_{2} \mathrm{O}$ est utilisé en salle d'opération, la surveillance du $\mathrm{N}_{2} \mathrm{O}$ constitue une façon acceptable de vérifier l'efficacité du système d'évacuation des gaz.

\section{La période préanesthésique}

Le département d'anesthésie devrait formuler les politiques concernant l'évaluation préanesthésique. 
Le principal objet de l'évaluation préanesthésique est d'obtenir les renseignements requis pour planifier la prise en charge anesthésique. Par conséquent, un médecin bien informé quant à la prise en charge anesthésique pour la procédure diagnostique ou thérapeutique proposée devrait documenter tous les aspects des antécédents médico-chirurgicaux du patient, le bilan de l'examen physique et les résultats des analyses de laboratoire pertinents à la prise en charge anesthésique. Les antécédents du patient devraient inclure les problèmes médicaux passés et actuels, la prise de médicaments récente et actuelle, les réactions ou réponses inhabituelles aux médicaments et tous les problèmes et complications associés aux anesthésies administrées antérieurement. Il y a lieu de connaître également les antécédents familiaux de réactions indésirables associées à l'anesthésie. Tout renseignement concernant l'anesthésie que le patient juge pertinent de signaler devrait également être noté. Il convient enfin d'inscrire au dossier médical de chaque patient le code de classification de l'American Society of Anesthesiologists (Annexe 2).

Dans les cas adaptés, la disponibilité d'un "Plan de soins avancés » (accord de représentation, directive préalable, « testament biologique », directive « ne pas réanimer », etc.) doit être vérifiée et son applicabilité à l'intervention proposée déterminée et documentée au dossier d'évaluation anesthésique.

Le chirurgien peut solliciter une consultation avec un anesthésiologiste. Les consultations médicales devraient être obtenues lorsque cela est indiqué.

Le bilan ou la consultation anesthésique préopératoire peut avoir lieu en clinique externe avant l'admission pour l'opération. Les indications concernant l'évaluation préalable à l'admission comprennent l'existence de problèmes médicaux importants (comorbidités), la nature de la procédure diagnostique ou thérapeutique proposée, et la demande du patient. La présence d'un parent/tuteur légal est nécessaire si le patient est un enfant ou n'est pas apte à fournir un consentement éclairé. Tous les patients devraient être informés que des dispositions seront prises pour rencontrer un anesthésiologiste s'ils souhaitent s'entretenir de leur prise en charge anesthésique avant leur admission à l'établissement. La clinique d'évaluation préopératoire devrait également permettre au personnel infirmier et aux autres membres du personnel de santé d'évaluer le patient. L'anesthésiologiste en charge du patient est responsable de l'évaluation préanesthésique finale durant la période préopératoire immédiate.

\subsection{Examens préopératoires}

Les examens de laboratoire ne devraient pas être réalisés sur une base régulière mais uniquement lorsque les résultats modifieront la prise en charge périopératoire. Les analyses de laboratoire devraient être réalisées lorsque l'état du patient, le traitement médicamenteux et la nature de l'intervention proposée les justifient. Les tests sanguins de laboratoire, les électrocardiogrammes et les radiographies du poumon de routine ne sont pas recommandés chez les patients asymptomatiques subissant une chirurgie à risque faible. Les chirurgies de cataracte, les chirurgies mammaires mineures, les interventions superficielles et bon nombre d'interventions ambulatoires mineures sont quelques exemples de chirurgies à risque faible. Pour obtenir une définition plus détaillée des chirurgies à faible risque et d'autres recommandations concernant les examens préopératoires, consultez la section Choisir avec soin du site de la SCA et les liens internet associés.

Voici quelques indications raisonnables pour réaliser des tests spécifiques :

\begin{tabular}{|c|c|}
\hline Test & Indications \\
\hline Formule sanguine complète & $\begin{array}{l}\text { - Chirurgie majeure exigeant la } \\
\text { détermination du groupe } \\
\text { sanguin et un test de dépistage } \\
\text { d'anticorps ou un test de } \\
\text { compatibilité } \\
\text { - Affection cardiovasculaire, } \\
\text { pulmonaire, rénale ou hépatique } \\
\text { chronique } \\
\text { - Tumeur maligne } \\
\text { - Anémie connue ou soupçonnée, } \\
\text { diathèse hémorragique ou } \\
\text { myélosuppression } \\
\text { - Patient de moins d'un an }\end{array}$ \\
\hline Test de falciformation & $\begin{array}{l}\text { - Patients ayant une prédisposition } \\
\text { génétique (électrophorèse de } \\
\text { l'hémoglobine si le test est } \\
\text { positif) }\end{array}$ \\
\hline $\begin{array}{l}\text { Rapport international normalisé } \\
\text { (RIN), temps de } \\
\text { thromboplastine partielle } \\
\text { activée (aPTT) }\end{array}$ & $\begin{array}{l}\text { - Anticoagulothérapie } \\
\text { - Diathèse hémorragique } \\
\text { - Maladie hépatique }\end{array}$ \\
\hline $\begin{array}{l}\text { Taux d'électrolytes et de } \\
\text { créatinine }\end{array}$ & $\begin{array}{l}\text { - Hypertension } \\
\text { - Néphropathie } \\
\text { - Diabète } \\
\text { - Maladie hypophysaire ou } \\
\text { surrénalienne } \\
\text { - Traitement avec diurétiques ou } \\
\text { digoxine, ou autres } \\
\text { médicaments affectant les } \\
\text { électrolytes }\end{array}$ \\
\hline Glycémie à jeun & $\begin{array}{l}\text { - Diabète (doit être répété le jour } \\
\text { de la chirurgie) }\end{array}$ \\
\hline Grossesse ( $\beta$-HCG) & $\begin{array}{l}\text { - Toute femme susceptible d'être } \\
\text { enceinte }\end{array}$ \\
\hline
\end{tabular}


continued

\begin{tabular}{ll}
\hline Test & Indications \\
\hline
\end{tabular}

Électrocardiogramme

\subsection{Lignes directrices concernant le jeûne}

Les règles concernant le jeûne devraient varier en fonction de l'âge du patient et de ses antécédents médicaux et s'appliquer à toutes les formes d'anesthésie, y compris les soins anesthésiques monitorés. Les interventions très urgentes ou urgentes doivent être réalisées après avoir examiné les risques qu'entraînerait leur report comparativement au risque d'aspiration du contenu de l'estomac. Le type et la quantité de nourriture absorbée doivent être pris en considération pour déterminer la durée du jeûne.

Avant une intervention non urgente, la durée minimale du jeûne devait être de

- Huit heures après un repas comprenant de la viande ou des aliments frits ou gras;

- Six heures après un repas léger (pain grillé et liquides clairs, par exemple) ou après l'ingestion de préparation pour nourrissons ou de lait non humain;
- Quatre heures après l'ingestion de lait maternel (aucun ajout n'est permis au lait maternel tiré);

- Deux heures après l'ingestion de liquides clairs.

Sauf contre-indication, il convient d'encourager adultes et enfants à boire des liquides clairs (eau, jus sans pulpe et thé ou café sans lait) jusqu'à deux heures avant une chirurgie non urgente.

La prémédication, lorsqu'elle est indiquée, devrait être prescrite par l'anesthésiologiste. L'ordonnance doit en préciser la dose, le moment et la voie d'administration.

Des lois provinciales ou la règlementation de l'établissement pourraient prescrire d'autres directives régissant l'administration de l'anesthésie.

\section{La période anesthésique}

\subsection{Préparation à l'anesthésie}

Avant le début de l'anesthésie, l'anesthésiologiste doit s'assurer que

1. La procédure anesthésique prévue a été expliquée au patient, y compris les risques reconnus et les techniques alternatives, et on a documenté cette explication;

2. Une évaluation adaptée de l'état du patient a été réalisée;

3. Tout le matériel qu'on prévoit nécessaire est accessible et en bon état de fonctionnement, y compris le matériel nécessaire au maintien de la température centrale (température centrale du patient $36-37^{\circ} \mathrm{C}$ );

4. On a accès à une source de réserve d'oxygène sous pression;

5. Tous les médicaments et agents qu'on prévoit nécessaires sont correctement identifiés - les étiquettes de médicament apposées par l'usager doivent être conformes à la norme de la CSA CAN/CSA- Z264.398 (R2005) (Annexe 1);

6. Jusqu'à ce qu'un système de connexion spécifique soit créé pour utilisation neuraxiale, les deux côtés de toutes les connexions de type Luer devraient être étiquetés; et

7. On a tenu compte des indications du fabricant quant à l'utilisation, à la manipulation et à la disposition de l'équipement et du matériel d'anesthésie.

\subsection{Délégation des soins aux patients}

L'anesthésiologiste est avant tout responsable du patient qu'il a sous ses soins. L'anesthésiologiste ou un assistant en anesthésie supervisé par l'anesthésiologiste doit 
demeurer constamment aux côtés du patient pour toute la durée d'une anesthésie générale, régionale majeure et intraveineuse monitorée, jusqu'à ce que le patient ait été confié aux soins du personnel de l'unité de soins compétente.

Si l'anesthésiologiste traitant quitte temporairement la salle d'opération, il doit confier les soins du patient à un autre anesthésiologiste, à un résident en anesthésie ou à un assistant en anesthésie. Lorsque l'anesthésiologiste traitant délègue les soins à un résident en anesthésie ou à un assistant en anesthésie, il demeure responsable de la prise en charge anesthésique du patient. Avant de déléguer les soins du patient à un assistant en anesthésie, l'anesthésiologiste doit s'assurer que l'état du patient est stable et que l'assistant en anesthésie est familier avec l'intervention chirurgicale ainsi qu'avec l'environnement et le matériel de la salle d'opération. L'anesthésiologiste traitant doit demeurer immédiatement disponible lorsque les soins sont délégués à un assistant en anesthésie.

Un anesthésiologiste peut brièvement confier les soins courants d'un patient dont l'état est stable à une personne compétente qui n'est pas un assistant en anesthésie qu'en cas de circonstances particulièrement exceptionnelles, pour se porter par exemple au secours d'un autre patient dont la vie est en danger. L'unique responsabilité de cette personne devrait être de surveiller le patient en l'absence de l'anesthésiologiste et de tenir l'anesthésiologiste informé jusqu'à son retour. Dans de telles circonstances, l'anesthésiologiste demeure responsable des soins prodigués au patient et se doit de tenir l'équipe de la salle d'opération au courant.

Le transfert peropératoire des soins entre deux anesthésiologistes doit être noté au dossier d'anesthésie et se conformer à un protocole structuré.

Il est inacceptable qu'un anesthésiologiste administre simultanément une anesthésie générale, une anesthésie régionale majeure (rachidienne, péridurale ou autre) ou une sédation consciente profonde (niveaux 4-6 sur l'échelle de sédation de Ramsay [RSS], voir Annexe 6) pour des interventions diagnostiques ou thérapeutiques concomitantes pratiquées sur plus d'un patient à la fois. Toutefois, il peut être admis, dans des circonstances particulières, qu'un anesthésiologiste supervise plus d'un patient chez lequel une sédation de 1-3 seulement sur la RSS est administrée, à condition qu'un individu ayant reçu une formation adéquate, qualifié, accrédité et approuvé par l'établissement de santé, soit constamment présent auprès de chaque patient recevant des soins. Il sera par contre admis, dans un service d'obstétrique, de surveiller simultanément plus d'une patiente à laquelle est administrée une analgésie régionale pour le travail. Chaque parturiente devra cependant être surveillée adéquatement par une personne compétente, suivant un protocole établi.
Lorsqu'un anesthésiologiste dispense des soins anesthésiques en vue d'un accouchement, une deuxième personne dûment formée doit se tenir prête à intervenir pour pratiquer la réanimation néonatale.

Il est inacceptable qu'un seul médecin administre une anesthésie simultanément à la réalisation d'une procédure diagnostique ou thérapeutique, exception faite des interventions réalisées par seule infiltration d'anesthésiques locaux.

\subsection{Monitorage du patient}

Le seul moniteur indispensable est la présence, à tous les instants, d'un médecin ou d'un assistant en anesthésie placé sous la supervision immédiate d'un anesthésiologiste et détenant la formation et l'expérience appropriées. Les moniteurs mécaniques et électroniques ne sont, au mieux, que des aides à la vigilance. Ces appareils aident l'anesthésiologiste à s'assurer de l'intégrité des organes vitaux et, en particulier, de la perfusion et de l'oxygénation satisfaisantes des tissus.

Il incombe à l'établissement de soins de santé de fournir et d'entretenir un équipement de monitorage qui respecte les normes en vigueur.

Il incombe au chef du département d'anesthésie de conseiller l'établissement de soins de santé au sujet de l'acquisition de l'équipement de monitorage et d'établir les normes de monitorage qui aideront à assurer la sécurité du patient.

Il incombe à l'anesthésiologiste de monitorer le patient qui est sous ses soins et de s'assurer que l'équipement de monitorage approprié soit disponible et fonctionne correctement. Une feuille de vérification préanesthésique (Annexe 3 ou équivalent) doit être remplie avant l'amorce de l'anesthésie.

Une posologie prudente, un monitorage vigilant et la neutralisation adéquate des bloqueurs neuromusculaires sont des éléments essentiels à la sécurité des patients. Un monitorage neuromusculaire devrait être utilisé lors de l'administration de bloqueurs neuromusculaires non dépolarisants.

Les directives de monitorage pour les soins standard aux patients s'appliquent à tous les patients recevant une anesthésie générale, une anesthésie régionale ou une sédation intraveineuse.

\subsection{Matériel de monitorage requis}

Le matériel de monitorage est catégorisé comme suit :

- Requis : Ces moniteurs doivent être utilisés sans interruption pendant toute la durée de l'administration de toute anesthésie. 
- Accessible en exclusivité pour chaque patient : Ces moniteurs doivent être accessibles à chaque poste de travail d'anesthésie, de sorte qu'ils puissent être utilisés sans délai.

- À portée immédiate : Ces moniteurs doivent être accessibles afin de faciliter leur utilisation sans délai indu.

Le matériel de monitorage suivant est requis :

- Un saturomètre;

- Un appareil permettant de mesurer la tension artérielle, directement ou sans effraction;

- Un électrocardiographe;

- Un capnographe, pour l'anesthésie générale et la sédation consciente profonde (RSS 4-6); et

- Un moniteur de gaz anesthésiques spécifique à l'agent, lorsque des agents anesthésiques par inhalation sont utilisés.

Le matériel de monitorage suivant doit être accessible en exclusivité pour chaque patient :

- Un appareil pour mesurer la température;

- Un stimulateur des nerfs périphériques, lors de l'utilisation de bloqueurs neuromusculaires;

- Un stéthoscope - précordial, œsophagien ou paratrachéal; et

- Un éclairage suffisant pour visualiser une partie exposée du patient.

Le matériel de monitorage suivant sera à portée immédiate :

- Un spiromètre pour mesurer le volume respiratoire;

- Un manomètre pour mesurer la pression du ballonnet du tube endotrachéal.

L'anesthésiologiste doit demeurer vigilant en tout temps, étant conscient que de brèves interruptions du monitorage continu puissent être inévitables et que, dans certaines circonstances, un moniteur pourrait faire défaut.

Les alarmes audibles et visuelles du saturomètre et du capnographe ne devraient pas être désactivées indéfiniment pendant le déroulement d'une anesthésie, sauf en cas de circonstances inhabituelles. L'alarme à tonalité variable, celle des pulsations cardiaques et l'alarme de seuil inférieur du saturomètre ainsi que l'alarme d'apnée du capnographe doivent émettre un signal audible et visible.

\subsection{Prise en charge périopératoire de la température}

Le monitorage de la température centrale du patient est fortement recommandé pendant les cas d'anesthésie générale et d'anesthésie régionale neuraxiale d'une durée de 30 min ou plus. En l'absence d'indications chirurgicales ou liées au patient concernant une hypothermie peropératoire, des systèmes de réchauffement du patient actifs, le contrôle de la température ambiante en salle d'opération et d'autres méthodes devraient être utilisés pour cibler une température centrale de $36-37^{\circ} \mathrm{C}$.

\subsection{Dossiers}

Toutes les variables physiologiques monitorées doivent être enregistrées à intervalles réguliers en fonction des circonstances cliniques. La fréquence cardiaque et la tension artérielle doivent être enregistrées au minimum toutes les cinq minutes. La saturation en oxygène doit être monitorée en continu et devrait être enregistrée à intervalles fréquents chez tous les patients. La concentration en dioxyde de carbone $\left(\mathrm{PCO}_{2}\right)$ télé-expiratoire doit être monitorée en continu et enregistrée à intervalles fréquents en cas d'intubation trachéale. On doit documenter au dossier anesthésique toute raison pour laquelle on déroge à ces directives de tenue de dossier. Les types de moniteurs, le matériel et les techniques, ainsi que l'heure, la posologie et la voie d'administration de tout médicament et liquide devraient être notés. Les soins peropératoires doivent être enregistrés.

Le dossier anesthésique doit inclure le niveau de conscience du patient, sa fréquence cardiaque, sa tension artérielle, sa saturation en oxygène et sa fréquence respiratoire tels que mesurés à l'arrivée en salle de réveil.

\section{La période postanesthésique}

\subsection{La salle de réveil}

Une salle de réveil doit être disponible dans tout établissement offrant des services anesthésiques. Des politiques administratives conformes aux règlements de l'établissement devront être appliquées de façon à coordonner les responsabilités des soins médicaux et infirmiers.

Le département d'anesthésie devrait endosser l'ensemble de la responsabilité administrative médicale pour la salle de réveil. Il devrait exister un manuel des politiques de la salle de réveil approuvé par les autorités médicales, infirmières et administratives compétentes.

L'anesthésiologiste devrait accompagner le patient en salle de réveil, transmettre les renseignements nécessaires au personnel infirmier de la salle de réveil dans le cadre d'un transfert structuré du protocole de soins, et rédiger les ordonnances nécessaires. Si indiqué cliniquement, une source d'oxygène d'appoint et des appareils de monitorage 
appropriés tels que, entre autres, un saturomètre portable, devraient être appliqués durant le transport à la salle de réveil. L'anesthésiologiste ne devrait déléguer les soins du patient à l'infirmier ou l'infirmière de la salle de réveil que lorsqu'il est assuré que le personnel infirmier pourra adéquatement observer et prendre soin du patient. L'anesthésiologiste ou un anesthésiologiste remplaçant désigné est responsable des soins postanesthésiques en salle de réveil. Le congé de la salle de réveil est sous la responsabilité de l'anesthésiologiste; cette responsabilité peut être déléguée en accord avec les politiques de l'établissement.

Une source d'oxygène d'appoint et une succion doivent être disponibles pour chaque patient en salle de réveil. Le matériel d'urgence nécessaire à la prise en charge des voies aériennes, la réanimation et au support vital doit être disponible en salle de réveil. Le matériel pour la prise en charge de voies aériennes difficiles doit être à portée immédiate en salle de réveil. Le monitorage utilisé en salle de réveil doit être adapté à l'état du patient et un éventail complet d'appareils de monitorage doit être disponible. Les alarmes des moniteurs doivent être en fonction, avec des paramètres d'alarme adaptés à l'état et à l'âge du patient. L'utilisation continue d'un saturomètre est requise pendant la phase initiale de récupération. Un capnographe est requis pour les patients intubés ou sous sédation profonde (RSS 4-6). Un moniteur d'apnée est recommandé chez les nourrissons nés à un âge gestationnel de moins de 50 semaines.

Un dossier détaillé de la période immédiate de réveil doit être tenu. Celui-ci doit inclure un enregistrement des signes vitaux ainsi que des autres aspects du traitement et de l'observation. Cette feuille d'observation fait partie du dossier médical permanent. Toute complication ayant un lien avec l'anesthésie doit être notée sur la feuille de la salle de réveil ou dans les notes d'évolution du dossier du patient.

Dans certaines situations, il peut être acceptable de transférer un patient directement vers d'autres unités de soins ou de passer outre la salle de réveil si un niveau de soins adapté est disponible dans une autre unité de l'établissement et s'il est noté au dossier anesthésique que le patient est jugé apte à ce transfert.

\subsection{Congé des patients après chirurgie d'un jour}

Le congé des patients après une chirurgie ambulatoire doit se faire en utilisant un plan formel de soins approuvé par l'institution et documenté dans les notes de soins prodigués aux patients. La prise en charge de la douleur et des complications postopératoires, ainsi que le suivi de routine et d'urgence, doivent tous faire l'objet d'instructions écrites spécifiques. Le patient doit être averti au sujet des synergies additives qu'il existe entre l'alcool et d'autres sédatifs, au sujet du danger de conduire ou d'utiliser des machines dangereuses dans la période postopératoire (dans la plupart des cas durant les 24 heures suivant l'opération), et au sujet de la nécessité d'attention de la part d'un adulte compétent dans la période postopératoire (dans la plupart des cas durant les 24 heures suivant l'opération).

\section{Lignes directrices pour l'analgésie régionale en obstétrique}

Les services d'anesthésie destinés aux parturientes comprennent l'analgésie obstétricale pour le travail - pour l'accouchement avec ou sans complication - ou pour les césariennes. Toutes les directives visant l'anesthésie administrée pour toute autre intervention diagnostique ou thérapeutique s'appliquent également à l'anesthésie obstétricale. Les directives de la présente section portent sur l'analgésie péridurale et la rachianesthésie pendant le travail. L'expression « analgésie régionale » désigne l'analgésie péridurale, la rachianesthésie et la combinaison des deux.

Ces directives sont passées en revue chaque année par la Section d'anesthésie obstétricale de la SCA et mises à jour au besoin. Chaque établissement peut décider d'élaborer des directives ou politiques supplémentaires pour des situations spécifiques dans lesquelles une analgésie régionale obstétricale est dispensée.

Sous la direction d'un anesthésiologiste, certains aspects du monitorage et de la prise en charge de l'analgésie régionale obstétricale peuvent être délégués à d'autres membres du personnel de santé. Chaque établissement doit s'assurer que ces personnes reçoivent les mêmes formation, certification, formation continue et recertification en analgésie régionale en obstétrique.

\subsection{Amorce de l'analgésie régionale en obstétrique}

1. Avant d'offrir une analgésie régionale en obstétrique, l'établissement doit disposer de protocoles de monitorage adaptés. Ces protocoles préciseront les types de monitorage requis et leur fréquence. En outre, ils préciseront clairement la manière de gérer les problèmes et urgences communément rencontrés et à qui faire appel en cas de besoin d'assistance.

2. Seuls les médecins ayant la formation, les privilèges hospitaliers et la certification nécessaires à fournir ces services peuvent pratiquer l'analgésie régionale en obstétrique. Il en va de même pour les stagiaires travaillant sous supervision.

3. L'analgésie régionale ne doit être amorcée et maintenue qu'aux endroits disposant du matériel et des médicaments de réanimation adaptés et immédiatement accessibles.

4. Le consentement éclairé doit être obtenu et noté au dossier médical. 
5. Un accès intraveineux doit être établi avant d'amorcer une analgésie régionale et maintenu tout au long de l'administration de l'analgésie régionale.

6. L'anesthésiologiste doit être immédiatement disponible jusqu'à ce que l'analgésie soit établie et que les signes vitaux de la patiente soient stables.

\subsection{Maintien de l'anesthésie régionale pendant le} travail

L'administration continue, sous perfusion, d'une faible dose d'anesthésiques locaux (dilués) par voie péridurale, avec ou sans ajouts, est associée à une incidence très faible de complications significatives. Par conséquent, il n'est pas nécessaire que l'anesthésiologiste reste présent ou soit immédiatement disponible pendant le maintien de l'analgésie péridurale par perfusion continue à condition que :

- L'on dispose de protocoles appropriés pour la prise en charge des patientes recevant une analgésie péridurale contrôlée par la patiente (APCP), et

- Que l'on puisse joindre l'anesthésiologiste pour obtenir conseils et instructions.

Un bolus d'anesthésiques locaux administré par cathéter péridural ou par un cathéter ou une aiguille qu'on présume positionné dans l'espace péridural peut entraîner des complications immédiates mettant la vie en danger. Par conséquent, lorsqu'un bolus d'anesthésiques locaux est administré par cathéter péridural (sauf pour l'APCP), un anesthésiologiste doit être disponible pour intervenir comme il se doit en cas de complications. Chaque département d'anesthésiologie devrait établir ses propres politiques concernant la disponibilité jugée adaptée d'un anesthésiologiste pour prendre en charge toute complication liée à l'analgésie régionale. Au moment d'élaborer ces politiques, chaque département devrait tenir compte du risque possible que présente l'injection d'un bolus d'anesthésiques locaux et des méthodes d'intervention en cas d'urgence.

\subsection{Absorption orale pendant le travail}

La vidange gastrique des aliments solides est retardée pendant le travail, et les analgésiques opioïdes peuvent la retarder encore davantage. Par conséquent, les parturientes ne devraient pas absorber d'aliments solides une fois le travail actif débuté. Comparativement aux aliments solides, les liquides clairs sont évacués relativement rapidement de l'estomac et absorbés par l'intestin grêle proximal, même pendant le travail. Par conséquent, chaque établissement devrait élaborer des protocoles concernant l'absorption de liquides clairs par les femmes en travail actif.

\section{Lignes directrices pour la prise en charge de la douleur aiguë à l'aide de l'analgésie neuraxiale}

Lorsque l'analgésie neuraxiale est prise en charge par des anesthésiologistes, l'incidence d'effets secondaires n'est pas plus élevée que lorsque des techniques alternatives de prise en charge de la douleur sont utilisées. En conséquence, lorsque son utilisation est indiquée, l'analgésie neuraxiale devrait être prise en charge par les anesthésiologistes.

Aux fins de ce guide, l'analgésie neuraxiale se définit comme l'administration intrathécale ou péridurale d'opioïdes et/ou d'anesthésiques locaux en vue du traitement de la douleur postopératoire ou d'autres problèmes de douleur aiguë. Ce guide vise à fournir aux anesthésiologistes les principes de prise en charge afin que l'analgésie neuraxiale soit pratiquée de manière à en maximiser les avantages et en minimiser les risques.

\subsection{Politiques administratives et éducatives}

Le département d'anesthésie devrait mettre sur pied un service de traitement de la douleur aiguë responsable de

1. L'élaboration des politiques et procédures en matière d'analgésie neuraxiale. La participation d'autres départements (par ex., soins infirmiers, pharmacie, chirurgie et gestion de l'équipement) doit être sollicitée au besoin.

2. La liaison avec les départements de chirurgie. Les chirurgiens doivent comprendre les critères de sélection des patients, les effets de l'analgésie neuraxiale sur l'évolution postopératoire normale et sur le mode de présentation des complications postopératoires, ainsi que les implications d'autres traitements, tels que l'anticoagulation prophylactique, sur l'analgésie neuraxiale.

3. L'éducation et la certification du personnel infirmier. Un programme de formation standardisé - comprenant la formation initiale, la certification et le maintien continu de la compétence - devrait être établi pour le personnel infirmier dispensant des soins aux patients recevant une analgésie neuraxiale.

Le personnel infirmer doit comprendre

- Le risque de dépression respiratoire, y compris la dépression respiratoire tardive, lors de l'administration d'opioïdes hydrophiles; 
- L'évaluation et la prise en charge de la dépression respiratoire;

- L'évaluation d'un bloc moteur et sensoriel;

- L'évaluation et la prise en charge de l'hypotension chez les patients recevant une analgésie neuraxiale; et

- Les signes et symptômes des complications rares mais catastrophiques que sont l'hématome ou l'abcès péridural.

\subsection{Politiques en matière d'administration de médicaments}

Chaque établissement devrait employer un nombre limité de solutions standard. Une fiche d'ordonnance préimprimée énumérant les solutions standard pour l'établissement est fortement recommandée. Avant d'administrer toute solution non standard dans l'établissement, l'anesthésiologiste devrait vérifier l'ordonnance avec le personnel infirmier et la pharmacie et en discuter les indications et toutes les précautions relatives à son emploi avec les infirmiers et infirmières responsables de l'administration du médicament et du monitorage du patient.

Le risque d'erreurs attribuables à une voie impropre d'injection du médicament doit être minimisé. Pour des perfusions continues ou une APCP, l'emploi de pompes inviolables distinctes de celles utilisées pour l'administration de solutés ou de médicaments est vivement recommandé. La tubulure entre les pompes de perfusion de l'analgésie neuraxiale et les cathéters ne devrait comporter aucun orifice susceptible de permettre une injection non intentionnelle de médicaments intraveineux.

La préparation des solutions devrait suivre une procédure standardisée. Toutes les solutions analgésiques devraient porter une étiquette indiquant la composition de la solution (opioïde, anesthésique local, ou les deux) ainsi que la voie d'administration appropriée (péridurale ou intraveineuse).

\subsection{Monitorage des patients et prise en charge des évènements indésirables}

Les patients auxquels est administrée une analgésie neuraxiale devraient être placés dans une chambre équipée d'oxygène et de succion. Des médicaments et du matériel de réanimation doivent être à portée immédiate. L'accès intraveineux doit être établi avant d'amorcer l'analgésie neuraxiale et, après cessation de l'analgésie neuraxiale, maintenu pendant toute la durée prévue des effets médicamenteux.

Le pansement qui maintient en place le cathéter péridural doit permettre l'examen du cathéter pour détecter tout mouvement et permettre l'inspection quotidienne du point d'entrée afin de déceler tout signe d'infection.
L'adoption de politiques standardisées au chapitre de la prise en charge des patients est préconisée. Les paramètres qu'il convient d'évaluer, la fréquence des évaluations, la documentation et les procédures de prise en charge des complications devraient être précisés. Un personnel de soins infirmiers en nombre suffisant doit être présent pour évaluer et prendre en charge les patients recevant une analgésie neuraxiale. Le monitorage devrait se poursuivre après cessation de l'analgésie neuraxiale jusqu'à ce que ses effets se soient dissipés.

Un anesthésiologiste doit être immédiatement disponible afin de conseiller le personnel infirmier sur des aspects tels que le titrage de la dose et la prise en charge des effets indésirables. Chaque établissement doté d'un service de traitement de la douleur aiguë doit veiller à ce qu'un anesthésiologiste soit disponible pour s'occuper directement des patients recevant une analgésie neuraxiale dans un délai approprié en fonction de la situation clinique. Chaque établissement devrait également déterminer les procédures en vue d'une prise en charge urgente de toute complication menaçant le pronostic vital.

D'autres médicaments, notamment les benzodiazépines ou les opioïdes parentéraux, peuvent causer une dépression respiratoire majeure chez les patients recevant une analgésie neuraxiale. Pour cette raison, les autres médecins ne devraient pas prescrire de sédatifs ou d'analgésiques à tout patient recevant une analgésie neuraxiale. Le service de traitement de la douleur aiguë devrait demeurer en charge de la thérapeutique analgésique et sédative jusqu'à dissipation des effets de l'analgésie neuraxiale.

\subsection{Péridurales et anticoagulation}

Les patients porteurs d'un cathéter péridural peuvent recevoir un traitement prophylactique d'anticoagulants à faible dose, si les précautions appropriées sont prises :

- Afin de minimiser le risque d'hématome péridural, l'installation et le retrait du cathéter ainsi que l'horaire d'administration de l'anticoagulant doivent être coordonnés de telle sorte qu'aucun effet anticoagulant significatif d'un point de vue clinique ne soit présent à ces moments.

- L'emploi d'agents anti-inflammatoires non stéroïdiens chez des patients recevant une analgésie neuraxiale est approprié, mais l'administration concomitante de ces médicaments ou d'autres antiagrégants plaquettaires et d'un anticoagulant peut augmenter le risque d'un hématome péridural.

- Lorsque l'analgésie neuraxiale est utilisée pour une prise en charge prolongée de la douleur postopératoire, 
il convient de déployer tous les efforts nécessaires afin d'éviter un bloc moteur des membres inférieurs.

- Le personnel infirmer doit connaître les signes et symptômes de l'hématome péridural. Toute altération de l'état neurologique ou toute apparition soudaine d'une douleur dorsale doit être immédiatement examinée.

Si une anticoagulothérapie complète est indiquée chez un patient porteur d'un cathéter péridural, l'anesthésiologiste devrait être consulté afin que le retrait du cathéter et l'amorce d'un traitement analgésique de substitution puissent être effectués avant le début de l'anticoagulothérapie.

\section{Lignes directrices pour l'exercice de l'anesthésie hors du milieu hospitalier}

Les principes fondamentaux, les exigences de formation, les techniques, le matériel et les médicaments utilisés pour la pratique de l'anesthésie ont été documentés dans d'autres sections de ce guide. Les lignes directrices suivantes concernent certains aspects propres à l'exercice de l'anesthésie à l'extérieur d'un établissement hospitalier.

\subsection{Sélection des patients}

Le statut physique des patients devrait être catégorisé d'une façon similaire à celle utilisée par l'American Society of Anesthesiologists (ASA) (Annexe 2). D'une manière générale, seuls les patients des classes ASA I et II devraient être retenus pour subir une anesthésie hors d'un établissement hospitalier. Les patients de statut ASA III pourraient être acceptés sous certaines conditions.

\subsection{Considérations préopératoires}

Une histoire de cas et un examen physique récent devraient paraître au dossier du patient, ainsi que les résultats des examens de laboratoire appropriés. Ces divers examens peuvent être exécutés par un autre médecin ou anesthésiologiste. La durée du jeûne avant une anesthésie devrait être conforme aux lignes directrices précédemment émises. Le patient devrait recevoir un feuillet d'information énumérant les directives relatives aux périodes pré- et postanesthésiques.

\subsection{Conduite de l'anesthésie}

Les installations des salles d'anesthésie et de réveil doivent répondre aux normes hospitalières de la CSA telles que définies dans les autres sections du présent guide. Les normes de soins et de monitorage doivent être les mêmes, quel que soit l'endroit où est administrée l'anesthésie.

Remerciements Nous tenons à remercier les anciens membres du Comité des normes de pratique de l'anesthésie qui ont apporté leurs contributions à des versions antérieures de ce Guide.

Conflits d'intérêt Tous les auteurs de cet article font partie du Comité des normes de la Société canadienne des anesthésiologistes (SCA). Aucun des auteurs n'a un quelconque intérêt financier ou commercial lié aux sociétés ou fabricants d'appareils médicaux dont il est fait mention dans cet article ou dans les annexes associées. Dr Gregory Dobson est président du Comité des normes de la SCA.

\section{Annexe 1: Association canadienne de normalisation - Normes concernant le matériel}

disponible en matériel électronique supplémentaire.

\section{Annexe 2: Classification de l'état de santé des patients, selon l'American Society of Anesthesiologists}

disponible en matériel électronique supplémentaire.

\section{Annexe 3: Liste de vérification préanesthésique}

disponible en matériel électronique supplémentaire.

\section{Annexe 4: Lignes directrices, normes et autres énoncés officiels disponibles sur l'internet}

L'Annexe 4 (disponible au : http://www.cas.ca/Francais/ Guide-d-exercice) offre une liste non exhaustive de sites contenant des déclarations officielles promulguées par d'autres associations médicales au Canada et ailleurs dans le monde. Cette liste est fournie aux membres de la SCA uniquement à des fins pratiques. La SCA n'est pas responsable de l'exactitude, de la mise à jour ou de la fiabilité du contenu de ces sites. La SCA n'offre aucune garantie à cet effet. Elle se dégage de toute responsabilité concernant l'information trouvée par le biais de ces liens et n'endosse pas nécessairement ces sites ou leur contenu. Cette liste contient l'adresse de sites qui sera mise à jour de façon périodique. 
Annexe 5: Exposé de principe sur les assistants en anesthésie : exposé de principe officiel de la Société canadienne des anesthésiologistes

disponible en matériel électronique supplémentaire.
Annexe 6: Exposé de principe sur la sédation consciente : exposé de principe officiel de la Société canadienne des anesthésiologistes

disponible en matériel électronique supplémentaire. 